\title{
Bartın Kent Ormanı Florası
}

\author{
Cevdet GÜMÜŞ ${ }^{1 *}$, Zafer KAYA \\ ${ }^{1}$ Bartın Üniversitesi, Bartın Meslek Yüksekokulu Bitkisel ve Hayvansal Üretim Bölümü, 74100, Bartın \\ ${ }^{2}$ Bartın Üniversitesi, Orman Fakültesi Orman Mühendisliği Bölümü, 74100, Bartın
}

\section{Öz}

İnsanların doğayla bütünleşme ve dinlenme ihtiyaçlarının karşılanması için ekolojik, sosyal ve kültürel amaçlı olarak planlanan ve bu amaçlar doğrultusunda belirli kriterler çerçevesinde özellikle kent halkının yararlanmasına sunulan kent ormanları, sosyal, kültürel, ekonomik ve ekolojik faydalarıyla kentte yaşayan insanlar için zorunlu bir ihtiyaç halini almıştır. Bartın Kent Ormanında yapılan floristik çalışmalar sonucunda araştırma alanında 50 familya, 131 cinse ait, 1’i endemik olmak üzere toplamda 158 adet takson olduğu tespit edilmiştir. Asteraceae araştırma alanında en çok cins ve takson içeren familya olarak belirlenmiştir.

Anahtar Kelimeler: Bartın, kent ormanı, takson, flora.

\section{Flora of Bartın Urban Forest}

\begin{abstract}
Urban forestry are forest areas that are planned for ecological, social and cultural purposes in order to meet the needs of people to integrate with nature and rest, and within the scope of this purpose, especially for the use of the city people. Urban forestry have become a compulsory need for the people living in the city with their social, cultural, economic and ecological benefits. 50 families, 131 genera and 158 taxa (one taxa is endemic) were determined as a result of the floristic studies in Bartın Urban Forest. Asteraceae has been identified as the family containing the most genus and taxa in the study area.
\end{abstract}

Keywords: Bartin, urban forest, taxa, flora. 


\section{Giriş}

Sanayileşme sonucu artan işgücü talebi dolasıyla artan hızlı kentleşme hava kirliliği, gürültü, trafik gibi sorunları beraberinde getirmiştir. İnsanların beden ve ruh sağlı̆ııı olumsuz yönde etkileyen bu faktörler, kent halkının şehir yakınlarındaki ormanlık alanlara olan talebini de giderek artırmıştır (İmal vd. 2007).

Kent Ormanı, kent içi ve yakın çevresinde doğal olarak bulunan veya yapay olarak tesis edilmiş, kentsel yapıya estetik ve işlevsel katkılar sağlayan, kent insanına farklı rekreatif olanaklar sunabilen ve kısa mesafede ulaşım imkanı bulunan orman alanlarıdır (Uslu ve Ayaşlıgil, 2007). Orman Genel Müdürlüğü ise kent ormanlarını, “insanların doğayla bütünleşme ve dinlenme ihtiyaçlarının karşılanması için ekolojik, sosyal ve kültürel amaçlı olarak planlanan ve bu amaç kapsamında belirli kriterler çerçevesinde özellikle kent halkının yararlanmasına sunulan ormanlık alanlar” olarak tanımlanmaktadır (OGM, 2005). Kent ormanlarının diğer ormanlardan farkı, kent içi ve yakın çevresinde oluşması ve gelişmesidir. Kirli havayı temizleme, istenmeyen görüntüleri perdeleme, manzara güzelliği oluşturma, trafik gürültüsünden arındırma, rüzgâr perdelemesi yapma, doğal peyzajın estetik etkisini artırma ve gölgeleme fonksiyonundan faydalanma gibi amaçlarla kurulan kent ormanları toplumun psikolojik, sosyolojik, ekonomik ve estetik değerlerine katkıda bulunurlar (Asan, 2015, Durkaya vd. 2016). Kent ormanları sosyal, kültürel, ekonomik faydaları dışında ekolojik faydalar da sağlamaktadır. Bu bağlamda kent ormanları hava kalitesini artırmada, göllerin ve nehirlerin kirleticilerle dolmasını engellemede, karbon tutarak atmosferdeki sera gazı oranının azaltılmasında önemli roller üstlenerek kent 1sısını düzenlemektedir. Kent ormanları aynı zamanda, biyoçeşitliliği korumakta, kent ortamına yaban hayatı zenginliği katmaktadır (Atmış ve Günşen 2015).

Ülkemizde kent halkının şehir yakınlarındaki orman kaynaklarından rekreasyonel faydalanma talebinin karşılanması amacıyla kent yakınlarındaki ormanlık alanlar “Kent Ormanı” olarak Tarım ve Orman Bakanlığı'na bağlı kuruluşlar tarafından kurularak halkın hizmetine sunulmuştur. Türkiye'de 2003 yılında uygulamaya konan "kent ormanı" projesi ile kısa sürede her il ve büyük ilçede kent ormanı kurulması amaçlanmıştır. 2020 yılı sonu itibariyle kurulan kent ormanı sayısı 112 adete ulaşmış olup, bunların 72'si il merkezlerinde, 40'ı ise ilçelerde yeralmaktadır (URL-1 2021).

Flora ise bir ülke, bir bölge ya da belirli bir yörenin sahip olduğu bitkilerin tamamına verilen addır (Yaltırık ve Efe, 1996). Anadolu, üç ana iklimin kesiştiği ve üç fitocoğrafik bölge bulundurması nedeniyle zengin biyolojik çeşitliliğe sahiptir. Farklı coğrafi bölgelerin bir ülkede buluşması ise çok nadir görülen bir özelliktir. Ülkemizde 11.707 bitki taksonu olup, bu taksonların 3.649'u endemiktir. Endemizm oranı \%31,82'dir (Güner vd..'den aktaran Tekebaş, 2017). 1755 m’ye varan yükseklik farklılıklarının oluşturduğu topografya ile buna bağlı olarak ortaya çıkan iklim çeşitliliği ve toprak yapısı Bartın'ın da bitki tür çeşitliliği bakımından oldukça zengin olmasını sağlamış, farklı araştırıcılar tarafından tür ve alttür olmak üzere toplam 1146 takson tespit edilmiştir (Aydın, 2005; Aktaş, 2006; Başaran, 1999 a; Başaran, 1999 b; Başaran ve Adıgüzel, 2001; Ekici, 2010; Kaya ve Başaran, 2006; Kaya ve Yaman, 2017; Palta, 2012; Sarıbaş vd. 1999; Sarı Nayim, 2010; Sarı Nayim ve Ayaşlıgil, 2015; Sarı Nayim, 2017; Tekebaş, 2017; Yatkın, 1996; Yılmaz, 2001).

Bartın Kent Ormanının florası hakkında yapılan literatür incelemesi neticesinde çalışmamız ile aynı dönemde yapılan "Bartın İli Kent Ormanı Alt Florasındaki Otsu Bitkilerin Bazı Özelliklerinin Belirlenmesi" isimli makalenin dışında bir bilimsel çalışmaya rastlanmamış olup, araştırma alanının genel florasının çalışılmadığı gözlenmiştir. Bu çalışmada Bartın il merkezinde yer alan Bartın Kent Ormanının florasını oluşturan taksonlar belirlenmeye çalışılmıştır.

\section{Materyal ve Metot}

\subsection{Materyal}

Bu çalışma 2016-2017 yıllarında yürütülmüştür. Araştırmanın materyalini Bartın Kent Ormanı sınırları içerisinde toplanan otsu ve odunsu bitki örnekleri oluşturmaktadır.

Çalışma alanı olarak seçilen Bartın kent ormanı; şehir merkezine 2 km mesafede, Hürriyet Mahallesi Toki

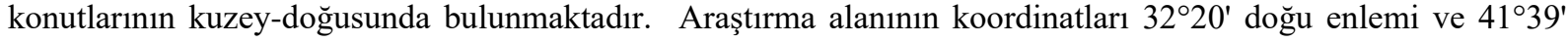
kuzey boylamıdır. Ortalama eğimin \%16 olduğu Kent ormanının denizden yüksekliği $80 \mathrm{~m}$ ile $195 \mathrm{~m}$ arasında değişmektedir. 1990 yılında sahilçamı ile kurulmuş olup, 30.09.2006 tarih ve 26305 sayılı resmî gazetede yayınlanan Mesire Yerleri Yönetmeliğine göre 2010 yılında kent ormanı olarak onaylanmıştır (Palta ve Genç Lermi 2017, Öztürk ve Bolat, 2014, Durkaya vd. 2016). 
Bartın'da yazları sıcak kışları serin geçen Karadeniz iklimi hüküm sürmektedir. Kentin denize yakın olması, yüksek dağ sıralarının kıyıya paralel olması, çoğunlukla kıyı şeridi üzerinde sıcaklık farklarının azalmasına, nemin artmasına ve balkanlardan gelen hava kütlelerinin etkisinde kalmasına neden olmaktadır. Araştırmanın yapıldığı yıllara ait aylık ortalama sıcaklık, nispi nem, yağış miktarı ve açık gün sayıları Tablo 1'de gösterilmiştir.

Tablo 1. Araştırmanın yapıldığı yıllara ait bazı ait iklim değerleri (Anonim, 2018).

\begin{tabular}{|c|c|c|c|c|c|c|c|c|c|c|c|c|c|}
\hline $\begin{array}{l}\text { İklim } \\
\text { Değerleri }\end{array}$ & Ay/Yıl & 1 & 2 & 3 & 4 & 5 & 6 & 7 & 8 & 9 & 10 & 11 & 12 \\
\hline \multirow{2}{*}{$\begin{array}{l}\text { Sicaklık } \\
\left({ }^{\circ} \mathrm{C}\right)\end{array}$} & 2016 & 2.5 & 8.4 & 9.6 & 13.7 & 15.9 & 21.5 & 22.8 & 23.9 & 18.3 & 13.5 & 8.1 & 2.0 \\
\hline & 2017 & 2.8 & 4.5 & 8.4 & 10.4 & 15.3 & 20.4 & 23.0 & 23.3 & 20.1 & 12.9 & 9.1 & 7.2 \\
\hline \multirow{2}{*}{$\begin{array}{l}\text { Nispi Nem } \\
\text { (\%) }\end{array}$} & 2016 & 92 & 85 & 74 & 73 & 80 & 76 & 75 & 77 & 78 & 83 & 84 & 86 \\
\hline & 2017 & 82 & 78 & 76 & 72 & 77 & 75 & 71 & 76 & 78 & 87 & 91 & 89 \\
\hline \multirow{2}{*}{$\begin{array}{l}\text { Yağıș } \\
\text { Mikt. } \\
\text { (mm) }\end{array}$} & 2016 & 294.8 & 126.8 & 43.0 & 63.9 & 103.8 & 44.8 & 18.4 & 187.0 & 105.3 & 81.8 & 95.2 & 165.9 \\
\hline & 2017 & 117.2 & 54.0 & 72.2 & 84.1 & 98.2 & 67.4 & 18.7 & 76.3 & 23.4 & 122.9 & 158.0 & 164.4 \\
\hline \multirow{2}{*}{$\begin{array}{l}\text { Açık gün } \\
\text { sayısı }\end{array}$} & 2016 & 0 & 6 & 5 & 10 & 5 & 14 & 18 & 13 & 18 & 6 & 10 & 3 \\
\hline & 2017 & 2 & 2 & 2 & 2 & 2 & 2 & 4 & 2 & 6 & 5 & 3 & 9 \\
\hline
\end{tabular}

\subsection{Metot}

Bartın Kent Ormanına 2016-2017 yıllarında iki vejetasyon dönemi boyunca 32 adet bilimsel gezi düzenlenmiştir. Gözlenen bitkilerin doğadaki fotoğrafları çekilerek herbaryum örnekleri toplanmıştır. Çiçek, meyve, tomurcuk, yaprak, gövde ve kökleri ile birlikte alınan herbaryum örnekleri gazete kağıtları arasına yerleştirilip, preslenmiştir. İlk zamanlarda kurutma kağıtları her gün, daha sonra üç günde bir değiştirilmiştir (Yaltırık, 1962). Preslenerek kurutulan bitki örnekleri kartonlara yapıştırılıp etiketleri yazılmış, Bartın Üniversitesi Orman Fakültesi Herbaryumu'ndaki dolaplara yerleştirilmiştir. Örneğin alındığı tarih, yer, yükselti, familya ve cins adı, çiçek rengi gibi bilgiler kayıt altına alınmıştır.

Bitkiler, Flora of Turkey and East Aegean Islands Cilt 1-9 (Davis et al., 1965-1985), Flora of Turkey and East Aegean Islands Cilt 10 (Davis et al.,. 1988), Flora of Turkey and East Aegean Islands Cilt 11 (Güner vd. 2000), Türkiye'nin Doğal Gymnospermleri (Yaltırık ve Akkemik, 2011), Peyzaj Bitkileri I (Zencirkıran, 2013), Orkidelerimiz Türkiye'nin Orkideleri (Sezik, 1984), Otsu Bitkiler Sistematiği (Yaltırık ve Efe, 1996) gibi eserlerden faydalanılarak teşhis edilmiştir. Türkçe isimlendirmesinde ise Güner vd. (2012)'den yararlanılmıştır.

\section{Bulgular ve Tartışma}

2016-2017 yıllarında Bartın Kent Ormanına düzenlenen bilimsel gezilerde, 50 familyaya ait, 1'i endemik olmak üzere toplamda 158 adet taksona ait herbaryum örnekleri toplanmış ve teşhisleri yapılmıştır. Bu taksonlar sistematik dizin (Bilimsel adı/Türkçesi/Fitocoğrafik bölgesi/Toplayan araştırıcılar) içerisinde aşağıda verilmiştir. Teşhis edilen bazı bitkilerin doğal ortamlarında çekilmiş fotoğrafları ise EK 1'de gösterilmiştir.

\section{APIACEAE}

1. Daucus carota L. /Yabani havuç/Bilinmeyen/16.04.2016/ CG\&ZK

2. Daucus guttatus SM. / Benekli havuç/ Bilinmeyen/ 24.4.2016/ CG\&ZK

3. Eryngium campestre var. virens (Link) Weins /Yer Kestanesi /Bilinmeyen/31.7.16/CG\&ZK

AMARYLLIDACEAE

4. Allium paniculatum L. subsp. paniculatum / sürüsalkım/Karadeniz/29.06.20216/CG\&ZK

ANACARDIACEAE

5. Cotinus coggygria Scop./Duman ağacı/Bilinmeyen/07.06.2017/CG\&ZK

6. Pistacia terebinthus L./Menengiç/Akdeniz/30.06.2016/CG\&ZK 


\section{ARACEAE}

7. Arum orientale M.Bieb./yılanyastığ $1 /$ Karadeniz/18.03.2016/CG\&ZK

\section{ARALIACEAE}

8. Hedera helix L. f. helix/duvar sarmaşığı/Bilinmeyen/30.10.2017/CG\&ZK

\section{ASPARAGACEAE}

9. Asparagus acutifolius L/Yabani kuşkonmaz/Akdeniz/29.06.2016//CG\&ZK

10. Muscari armeniacum Leichtlin. ex Baker./gavurbaş1/Yaygın/18.03.2017/CG\&ZK

11. Ornithogalum fimbriatum Willd./kirpi sasal/D.Akdeniz/20.03.2016/CG\&ZK

12. Ornithogalum narbonense L. /akbaldır/Akdeniz/22.05.2016/CG\&ZK

13. Ruscus aculeatus L./tavşanmemesi/Bilinmeyen/22.11.2016/CG\&ZK

\section{ASTERACEAE}

14. Bellis perennis L./koyungözü/Avrupa-Sibirya/09.03.2017/CG\&ZK

15. Bellis sylvestris Cirillo/Çayır papatyası/Akdeniz//09.03.2017/CG\&ZK

16. Carduus pycnocephalus L. subsp. albidus soymac1/Bilinmeyen/31.07.2016/CG\&ZK

17. Carlina corymbosa L/Kırkbaş dikeni/Akdeniz/01.08.2016/ CG\&ZK

18. Carlina vulgaris L./Deli domuzdikeni /Bilinmeyen/01.08.2016/ CG\&ZK

19. Carthamus lanatus L./ devedikeni/Bilinmeyen/ 30.06.2016/ CG\&ZK

20. Cichorium inthybus L./hindiba/Bilinmeyen/30.06.2016/CG\&ZK

21. Cirsium hypoleucum DC./ vişne kangalı/Karadeniz/13.05.2016/CG\&ZK

22. Cota triumfetti (L.) J.Gay / Yamaç papatyas1/ Bilinmeyen/ 29.05.2016 /CG\&ZK

23. Crepis sancta subsp. obovata (Boiss. \& Noë) Babc. yumurtakıskıs1/Bilinmeyen /18.03.2016/CG\&ZK

24. Eupatorium cannabinum L./ Koyun pitrağ $1 /$ Avrupa-Sibirya /18.10.2016/ / CG\&ZK

25. Erigeron acris L./ Mavi şifaotu/ Bilinmeyen/ 09.11.2016/ CG\&ZK

26. Helminthotheca echioides (L.) Holub /Billurdüğme/Bilinmeyen/18.10.2016/CG\&ZK

27. Inula britannica L./çayır andızı/ B.O.Karadeniz/ 29.05.2016/ CG\&ZK

28. Inula salicina L. / su andizotu /Avrupa-Sibirya/26.06.2017/ CG\&ZK

29. Jurinea consanguinea DC./ Geyikgöbeği /Bilinmeyen /22.5.2016/ CG\&ZK

30. Jurinea mollis (L.) Rchb./ Yaban göbeği / Bilinmeyen/ 22.05.2016/ CG\&ZK

31. Leontodon saxatilis Lam.subsp. saxatilis /geç aslandişi/ Avrupa-Sibirya/09.11.2016/CG\&ZK

32. Leontodon tuberosus L./ Yumrulu aslandiși/Akdeniz/ 26.04.2016//CG\&ZK

33. Matricaria chamomilla L. var. recutita (L.) Fiori./alman papatyasi/Bilinmeyen/29.06.2016/CG\&ZK

34. Pallenis spinosa (L.) Cass. / Diken otu/ Akdeniz /29.05.2016 /CG\&ZK

35. Petasites hybridus (L.) "G.Gaertn., B.Mey. \& Scherb. /kabalak/Karadeniz/02.11.2017/ CG\&ZK

36. Scorzonera mollis M.Bieb./Yakıtu/İran-Turan/20.03.2016/ CG\&ZK

37. Sonchus asper (L.) Hill. subsp. glaucescens (Jord.) Ball./gevirtlek/Yaygın/09.11.2016/CG\&ZK

38. Tanacetum parthenium (L.) Sch.Bip./Gümüşdüğme/ Bilinmeyen/22.05.2016/CG\&ZK

39. Taraxacum campylodes G.E.Haglund /kars çıtlı̆̆1/Bilinmeyen/03.04.2016/CG\&ZK

40. Tussilago farfara L./öksürükotu/Avrupa-Sibirya/26.02.2017/ CG\&ZK

\section{BETULACEAE}

41. Carpinus betulus L./gürgen/Avrupa-Sibirya/22.5.2016/CG\&ZK

\section{BORAGINACEAE}

42. Alkanna tinctoria (L.) Tausch /Havaciva/ Akdeniz/ 03.04.2016/ CG\&ZK

43. Buglossoides arvensis subsp. sibthorpiana (Griseb.) R. Fern / tarla taşkeseni / Bilinmeyen/29.05.2016 / CG\&ZK

44. Cerinthe minor L./ Livarotu /Avrupa-Sibirya/ 26.10.2016/ CG\&ZK

45. Echium angustifolium Mill./ K1zılc1k dikeni /D.Akdeniz/29.06.2016/CG\&ZK

46. Lithospermum purpurocaeruleum L. / Morumsu Taşkesenotu / Avrupa-Sibirya /29.05.2016/ CG\&ZK

47. Myosotis arvensis (L.) Hill. subsp. arvensis/kardeşboncuğu/Avrupa-Sibirya/13.05.2016/CG\&ZK

48. Onosma taurica Willd./ Emzikotu /Bilinmeyen /24.04.2016/CG\&ZK

49. Trachystemon orientalis (L.) G.Don./kaldirik/Karadeniz/18.03.2017/CG\&ZK

\section{BRASSICACEAE}

50. Barbarea vulgaris R.Br.subsp. vulgaris/nicarotu/Bilinmeyen/08.04.2016/CG\&ZK 
51. Calepina irregularis (Asso.) Thell./top hardal/Bilinmeyen/08.04.2016/CG\&ZK

52. Lepidium campestre (L.) Aiton./horozcuk/Bilinmeyen/16.04.2016/CG\&ZK

\section{CAPRIFOLIACEAE}

53. Knautia degenii Borbas ex Formanek./has eşekkulağ1/Akdeniz/29.04.2016/CG\&ZK

54. Scabiosa columbaria L./uyuzotu/Bilinmeyen/29.05.2017/CG\&ZK

\section{CARYOPHYLLACEAE}

55. Stellaria media (L.) Vill. /kuşotu/Bilinmeyen/09.03.2017/CG\&ZK

\section{CISTACEAE}

56. Cistus creticus L./ Laden/ Omni Akdeniz /.29.05.2017/CG\&ZK

57. Helianthemum nummularium (L.) Mill./ Güngülü /Bilinmeyen/29.05.2017/ CG\&ZK

\section{CONVOLVULACEAE}

58. Calystegia silvatica (KIT.) GRISEB. / Boyatan sarmaşık / Bilinmeyen / 22.5.2016/ CG\&ZK

59. Convolvulus arvensis L./tarla sarmaşığı/Bilinmeyen/07.06.2017/CG\&ZK

60. Convolvulus cantabrica L. /Çadırçiçeği /Bilinmeyen/07.06.2017/CG\&ZK

61. Ipomoea purpurea (L.) Roth/ Kahkaha çiçeği / Avrupa-Sibirya/01.08.2016/ CG\&ZK

\section{CORNACEAE}

62. Cornus sanguinea L. subsp.sanguinea/kiren/Bilinmeyen/30.10.2017CG\&ZK

\section{CUPRESSACEAE}

63. Juniperus oxycedrus L./ Katran Ardıcı/Bilinmeyen/21.07.2016/ CG\&ZK

\section{CYPERACEAE}

64. Carex panicea L./darı ayakotu/Avrupa-Sibirya/18.03.2016/CG\&ZK

\section{DENNSTAEDTIACEAE}

65. Pteridium aquilinum (L.)Kuhn. /Eğrelti/ Karadeniz./03.11.2017/CG\&ZK

\section{DRYOPTERIDACEAE}

66. Dryopteris filix-mas (L.) Schott /erkek eğrelti /Bilinmeyen / 29.05.2016/ CG\&ZK

\section{EUPHORBIACEAE}

67. Euphorbia paralias L. /kum sütleğeni/Akdeniz/25.03.2016/CG\&ZK

68. Euphorbia peplus L. var. peplus/bahçe sütleğeni/Akdeniz/25.03.2016/CG\&ZK

69. Euphorbia stricta L./katı sütleğen/Avrupa-Sibirya/24.04.2016/CG\&ZK

70. Euphorbia seguieriana subsp. niciciana (Borbás ex Novák) Rech.f./ekin sütleğeni /Bilinmeyen/ 09.03.2017/CG\&ZK

\section{FABACEAE}

71. Argyrolobium biebersteinii P.W.Ball / Ac1 collik / Bilinmeyen/ 20.03.2016/ CG\&ZK

72. Bituminaria bituminosa (L.) C.H. Stirt.Sin.Psoralea bituminosa/asfaltotu/Akdeniz/29.05.2016/CG\&ZK

73. Coronilla varia L. / Körigen /Bilinmeyen 26.06.2016/ CG\&ZK

74. Cytisus hirsutus L. / Keçi Tırfilı / Bilinmeyen/ 18.03.2016/ CG\&ZK

75. Dorycnium graecum (L.) Ser. /ak kaplanotu/Karadeniz/30.06.2016/CG\&ZK

76. Genista tinctoria L. /boyacı katırtırnağ1/boyacı otu/Avrupa-Sibirya/29.06.2016/CG\&ZK

77. Securigera varia (L.) Lassen/ Körigen /Akdeniz/07.06.2017CG\&ZK

78. Spartium junceum L./ Katırtırnağ1/ Akdeniz/ 24.04.2016/ CG\&ZK

79. Trifolium pratense var. sativum Schreb./çayır üçgülü/Bilinmeyen/09.11.2016/CG\&ZK

\section{FAGACEAE}

80. Quercus petraea (Matt.) Liebl. subsp. iberica (Steven ex Bieb.) Krassiln./ballık meşesi/Bilinmeyen/26.10.2017/CG\&ZK

\section{GENTIANACEAE}

81. Blackstonia perfoliata (L.) Huds./ deli şıra /Akdeniz/ 30.06.2016/ CG\&ZK

82. Centaurium erythraea Rafn. subsp. erythraea/kırmızı kantaron/Avrupa-Sibirya/07.06.2017/CG\&ZK 


\section{GERANIACEAE}

83. Erodium cicutarium (L.) L’Her. subsp. cicutarium/iğnelik /Yaygı/ 24.03.2017/CG\&ZK

84. Geranium dissectum L./dilimli 1tır/Bilinmeyen/16.04.2016/CG\&ZK

85. Geranium molle L. /yumuşak 1tır/Bilinmeyen/16.04.2016/CG\&ZK

\section{HYPERICACEAE}

86. Hypericum perforatum L. $\quad$ subsp.veronense (Schrank)H.Linb./sar1 kantaron/Bilinmeyen/29.06.2016/CG\&ZK

\section{IRIDACEAE}

87. Iris sintenisii Janka subsp. sintenisii /çatal süsen/Avrupa-Sibirya/22.05.2016/CG\&ZK

88. Crocus ancyrensis (Herb.) Maw End./ Ankara çiğdemi / İran-Turan /18.03.2016/CG\&ZK END.

89. Crocus speciosus M.Bieb. / çayır çiğdemi/ Bilinmeyen/ 09.11.2016/CG\&ZK

\section{LAMIACEAE}

90. Ajuga reptans L. /meryemsaçı/Avrupa-Sibirya/16.04.2016/CG\&ZK

91. Ajuga chamaepitys (L.) Schreb./ Kisamahmut Otu/ Bilinmiyor/29.06.2016/CG\&ZK

92. Clinopodium vulgare $\quad$ L. $\quad$ subsp.arundanum(Boiss.)Nyman./kamış fesleğen/Bilinmeyen/18.08.2017/CG\&ZK

93. Clinopodium nepeta (L.) Kuntze.subsp.glandulosum Sin. Calamintha nepeta/sümüklü fesleğen/Karadeniz/26.10.2016/CG\&ZK

94. Lamium purpureum L. var. purpureum/ballıbaba/Avrupa-Sibirya/26.03.2016/CG\&ZK

95. Mentha pulegium L. /yarpuz/Bilinmeyen/21.07.2016/CG\&ZK

96. Origanum vulgare subsp. viridulum (Martrin-Donos) Nyman / istanbul kekiği / Bilinmeyen/ 29.06.2016/ CG\&ZK

97. Salvia virgata Jacq. /fatmanaotu/İran-Turan/01.08.2016/CG\&ZK

98. Salvia forsskaolei L/ dolmayaprağı /Karadeniz /29.06.2016/CG\&ZK

99. Sideritis montana L. / Karaçay/ Akdeniz/ 21.7.2016/ CG\&ZK

100.Stachys annua (L.) L. subsp. annua var. annua /hac1osmanotu/Yaygın/09.11.2016/CG\&ZK

101.Teucrium polium L. /Acıyavşan / Bilinmeyen /18.03.2016/ CG\&ZK

\section{LINACEAE}

102.Linum bienne Mill. /deli keten/ Türkiye/Akdeniz/09.11.2016/CG\&ZK

MALVACEAE

103.Alcea rosea L./gülhatmi/ Bilinmeyen/ 29.06.2016/CG\&ZK

OLEACEAE

104.Ligustrum vulgare L. /kurtbağr1/Avrupa-Sibirya/22.05.2016/CG\&ZK

105.Phillyrea latifolia L./ Akça kesme/ Akdeniz/ 26.10.2016/CG\&ZK

\section{ORCHIDACEAE}

106.Anacamptis coriophora (L.) R.M.Bateman, Pridgeon \& M.W.Chase/pirinççiçeği /Bilinmeyen/ 29.05.2017/ CG\&ZK

107.Anacamptis pyramidalis (L.) Rich. / Çam salebi/ Bilinmeyen/29.05.2017/ CG\&ZK

108. Cephalanthera epipactoides Fisch. \& C.A.Mey./Ana çamçiçeği /D.Akdeniz/29.05.2017/CG\&ZK

109.Neotinea tridentata (Scop.) R.M.Bateman, Pridgeon \& M.W.Chase / Tavşantopuğu /Akdeniz/ 24.04.2016/ CG\&ZK

110.Ophrys apifera Huds./ arı salebi/Akdeniz/29.05.2017/CG\&ZK

111.Ophrys umbilicata Desf./ sinek salebi/ Bilinmeyen/29.05.2017 CG\&ZK

112.Ophrys mammosa Desf

Tersch.\&Devillers)Kreutz./akkedikulağı/Akdeniz/03.04.2016/CG\&ZK

113.Orchis laxiflora Lam. subsp. laxiflora /salep sümbülü/Akdeniz/24.04.2016/CG\&ZK

114.Orchis purpurea Huds./ Hasanc1k / Avrupa-Sibirya / 03.04.2016/CG\&ZK

115.Serapias orientalis(Greuter) H.Baumann\&Künkele subsp. orientalis/dillikulak / D.Akdeniz / 29.05.2017 / CG\&ZK

116.Platanthera chlorantha (Custer) Rchb./ çarpık salep / Avrupa-Sibirya /22.05.2016/ CG\&ZK 
OROBANCHACEAE

117.Bartsia trixago L. / Karaballıbaba / Bilinmeyen/ 22.05.2016/ CG\&ZK

OXALIDACEAE

118.Oxalis corniculata L. /sarı ekşiyonca/Kozmopolit/09.11.2016/CG\&ZK

PINACEAE

119.Pinus pinaster Ait. /sahil çamı/Bilinmeyen/29.10.2017/CG\&ZK

PLANTAGINACEAE

120.Antirrhinum majus L./ Aslanağz1/ B. Akdeniz/ 29.05.2017/CG\&ZK

121.Digitalis ferruginea L./ yüksükotu / Avrupa-Sibirya / 30.06.2016/CG\&ZK

122.Globularia vulgaris L./ deli küreçiçeği / Bilinmeyen//18.03.2016//CG\&ZK

123. Veronica chamaedrys L. /cancan/Avrupa-Sibirya/03.04.2016/CG\&ZK

124.Veronica persica Poir./curcamuk/Bilinmeyen/16.04.2016/CG\&ZK

125.Veronica serpyllifolia L./güzelnane/Bilinmeyen/08.04.2016/CG\&ZK

POACEAE

126.Avena barbata Pott ex Link/ narin yulaf / Akdeniz/29.05.2017/CG\&ZK

POLYGALACEAE

127.Polygala supina Schreb. /Bilinmeyen/24.04.2016/CG\&ZK

POLYGONACEAE

128.Rumex crispus L./ labada/Yaygın/22.05.2016/CG\&ZK

PRIMULACEAE

129.Anagallis arvensis L. var. arvensis/farekulağı/Bilinmeyen/22.05.2016/CG\&ZK

130.Anagallis arvensis var. caerulea (L.) Gouan/ Mavimsi farekulağı / Bilinmeyen/22.05.2016/ CG\&ZK

131.Cyclamen coum Mill. subsp. coum/yersomunu/Bilinmeyen/19.01.2017/CG\&ZK

132.Primula acaulis subsp. rubra (Sm.) Greuter \&Burdet./evvelbahar çiçeği/Karadeniz/26.02.2017/CG\&ZK

\section{RANUNCULACEAE}

133.Clematis vitalba L./akasma/Bilinmeyen/22.05.2016/CG\&ZK

134.Clematis viticella L / Yakmuk/ Bilinmeyen/ 07.06.2017/ CG\&ZK

135.Helleborus orientalis Lam. /çöpleme/Karadeniz/18.03.2016/ CG\&ZK

136.Ranunculus constantinopolitanus(DC.) d'Urv. /kağıthane çiçeği/Yaygın/03.04.2017/CG\&ZK

137.Ficaria verna subsp. ficariiformis (Rouy

$\&$

Foucaud)

B.Walln./arpacıksalepi/Bilinmeyen/26.02.2017/CG\&ZK

\section{ROSACEAE}

138.Agrimonia eupatoria L./Koyunotu, fitıkotu/ Bilinmeyen/01.08.2016/CG\&ZK

139.Crataegus monogyna Jacq. subsp. monogyna /yemişen/Bilinmeyen/18.10.2016/CG\&ZK

140.Filipendula vulgaris Moench / çayırmelikesi/ Avrupa-Sibirya / 26.04.2016/CG\&ZK

141.Potentilla erecta (L.) Rausch./kurtpençesi/Bilinmeyen/29.06.2016//CG\&ZK

142.Potentilla recta L. / Su parmakotu / Bilinmeyen /29.05.2016/ CG\&ZK

143.Potentilla reptans L./reşatınotu/Yaygın/15.05.2016/CG\&ZK

144.Pyrus communis L./ Armut/ Bilinmiyor/22.05.2016/CG\&ZK

145.Pyracantha coccinea Roem./ateş dikeni/Bilinmeyen/01.08.2016/CG\&ZK

146.Rosa canina L. /kuşburnu/Bilinmeyen/01.05.2016/CG\&ZK

147.Rubus canescens DC. var. canescens DC. /çoban kösteği/Avrupa-Sibirya/04.06.2016/CG\&ZK

\section{RUBIACEAE}

148.Galium verum L./ yoğurtotu /Avrupa-Sibirya/29.06.2016/CG\&ZK

149.Asperula involucrata Wahlenb / Akça belumotu / Karadeniz/22.05.2016/ CG\&ZK

SANTALACEAE

150.Osyris alba L. / Süpürge çalısı /Akdeniz/ 22.05.2016/CG\&ZK 
SCROPHULARIACEAE

151.Scrophularia scopolii Hoppe ex Pers. var. scopolii/el köpürten/Yaygın/20.03.2017/CG\&ZK

SMILACACEAE

152.Smilax excelsa L./dikenucu//Karadeniz/07.06.2017/ CG\&ZK

SOLANACEAE

153.Solanum americanum Mill.Sin.S.nigrum/ it üzümü/Kozmopolit/26.10.2016/CG\&ZK

154.Solanum dulcamara L. /sofur/Avrupa-Sibirya/18.10.2016/CG\&ZK

THYMELAEACEAE

155.Daphne pontica L. subsp.pontica /sırımağu/Karadeniz/22.5.2016/CG\&ZK

URTICACEAE

156.Urtica dioica L. subsp. dioica /1sırgan/Yaygın/30.06.2016/ CG\&ZK

ULMACEAE

157.Ulmus glabra Huds./dağ karaağaç/Avrupa-Sibirya/18.10.2017/CG\&ZK

VIOLACEAE

158.Viola alba subsp.dehnhardtii(Ten.)W.Becker./meşe menekşesi/Bilinmeyen/09.03.2017/CG\&ZK

Araştırma alanından toplanan bitki taksonlarının fitocoğrafik bölgelere göre dağılımı; 42 (\%26,58) takson Avrupa-Sibirya (Euro-Siberian), 30 (\%18,99) takson Akdeniz (Mediterranean), 3 (\%1,90) takson İran-Turan (Irano-Turanian) ve $83(\% 52,53)$ takson Geniş Yayılışlı ve Coğrafik Yayılışı Bilinmeyenler olarak belirlenmiştir (Tablo 2).

Tablo 2. Çalışma alanında saptanan taksonların fitocoğrafik bölgelere göre dağılımı.

\begin{tabular}{lll}
\hline Fitocoğrafik Bölge & Takson Sayısı & Oransal Dağılımı \\
\hline Avrupa-Sibirya (Euro-Siberian) & 42 & 26,58 \\
Akdeniz (Mediterranean) & 30 & 18,99 \\
İran-Turan (Irano-Turanian) & 3 & 1,90 \\
Geniş Yayılışlı ve Coğrafik Yayılışı Bilinmeyenler & 83 & 52,53 \\
TOPLAM & $\mathbf{1 5 8}$ & $\mathbf{1 0 0}$ \\
\hline
\end{tabular}

Araştırma alanında toplam 131 cins bulunmaktadır. Asteraceae 22 cins $(\% 16,80)$ ile en çok cins içeren familyadır. Asteraceae familyasını 9'ar cins (\%6,87) ile Fabaceae ve Lamiaceae, 8'er cins (\%6,11)ile Boraginaceae ve Rosaceae $(\% 6,25)$ ile izlemiştir. Araştırmada en çok cins içeren familyalar ve bunların araştırma alanındaki toplam cins sayısına oranları Tablo 3’te gösterilmiştir.

Tablo 3. Araştırma alanında en çok cins içeren bitki familyaları ve oranları

\begin{tabular}{lll}
\hline Familya & Cins Sayısı & Toplam Cins Sayısına Oranı (\%) \\
\hline Asteraceae & 22 & 16,80 \\
Fabaceae & 9 & 6,87 \\
Lamiaceae & 9 & 6,87 \\
Boraginaceae & 8 & 6,11 \\
Rosaceae & 8 & 6,11 \\
Orchidaceae & 7 & 5,34 \\
Asparagaceae & 4 & 3,05 \\
Plantaginaceae & 4 & 3,05 \\
Brassicaceae & 3 & 2,29 \\
Convolvulaceae & 3 & 2,29 \\
Primulaceae & 3 & 2,29 \\
Diğerleri & 51 & 38,93 \\
TOPLAM & $\mathbf{1 3 1}$ & $\mathbf{1 0 0}$ \\
\hline
\end{tabular}


Araştırma alanında 158 takson tespit edilmiştir. Tür ve tür altı seviyede en çok takson içeren familya cins sayısı sıralamasına paralel bir şekilde $27(\% 17,09)$ takson ile Asteraceae yine ilk sırayı almış, bunu 12 takson $(\% 7,60)$ ile Orchidaceae ve Lamiaceae izlemiștir. Cins sayısı bakımından 6.sırada yer alan Orchidaceae familyasının takson sayısı bakımından 2.sırayı alması dikkate değer bulunmuştur (Tablo 4).

Tablo 4. Araştırma alanında en çok takson içeren bitki familyaları ve oranları.

\begin{tabular}{lll}
\hline Familya & Takson Sayısı & Toplam Takson Sayısına Oranı (\%) \\
\hline Asteraceae & 27 & 17,09 \\
Orchidaceae & 12 & 7,60 \\
Lamiaceae & 12 & 7,60 \\
Rosaceae & 10 & 6,33 \\
Fabaceae & 9 & 5,70 \\
Boraginacee & 8 & 5,06 \\
Plantaginaceae & 6 & 3,80 \\
Asparagaceae & 5 & 3,16 \\
Ranunculaceae & 5 & 3,16 \\
Diğerleri & 64 & 40,50 \\
TOPLAM & $\mathbf{1 5 8}$ & $\mathbf{1 0 0}$ \\
\hline
\end{tabular}

Araştırma alanı endemizm oranı bakımından incelendiğinde ise endemizm oranının düşük olduğu $(\% 0,63)$ tespit edilmiştir. Yapılan bilimsel gezilerde yalnızca 1 adet endemik türe (Crocus ancyrensis (Herb.) Maw) rastlanmış olup, Ekim vd. (2000)'e göre (Türkiye Bitkileri Kırmızı Kitabı) göre LR (lc) (Az endişe verici) kategorisinde olduğu görülmüştür.

\section{Sonuç ve Öneriler}

Kent ormanı, insanların doğayla bütünleşme ve dinlenme ihtiyaçlarının karşılanması için ekolojik, sosyal ve kültürel amaçlı olarak planlanan ve bu amaç kapsamında belirli kriterler çerçevesinde özellikle kent halkının yararlanmasına sunulan ormanlık alanlar olup, sağlık, rekreasyon, eğitim vb. gibi birçok hizmeti topluma sunabilecek doğa parçalarıdır. Kent ormancılığı çalışmaları, kent halkının ağaç ve ağaç varlığını çok yönlü yararları ile tanıması ve algılaması, ormancılığın şehir planlama ile entegre edilmesi, kentlerle kent çevresi ormanlar arasındaki ilişkilerin dengelenmesi gibi amaçlarla yapılmakta ve karbon emisyonunu azaltma, hava kirliliğini engelleme, mikro klimayı düzenleme ve rekreasyon alanları yaratma gibi hizmetler sunmaktadır.

2010 yılında onaylanarak halkın kullanımına açılan Bartın Kent Ormanı halkın rekreasyon ihtiyaçlarının karşılanması yanında özellikle sahip olduğu biyoçeşitlilik ile de büyük önem arz etmektedir. 2016-2017 yıllarında gerçekleştirilen bu çalışmada Bartın Kent Ormanı’nın bitki çeşitliliği bakımından oldukça zengin bir floraya sahip olduğu belirlenmiş, Bartın Kent Ormanı alanı içerisinde 50 familya, 131 cinse ait 1'i endemik olmak üzere toplamda 158 adet takson bulunduğu tespit edilmiştir. Asteraceae, araştırma alanında en çok cins ve takson içeren familya olarak belirlenmiştir. Endemizm oranı ise \%0,63 olarak saptanmıştır. Nitekim Palta ve Genç Lermi (2017) de Bartın Kent Ormanı alt florasındaki otsu bitkilerin özelliklerini belirlemek amacıyla yaptıkları çalışmalarında biyoçeşitliliğin önemine vurgu yaparak, Bartın Kent Ormanının kontrolsüz bir şekilde kullanılmaya devam edilmesi durumunda, \%13'lük vejetasyonla kaplı olmayan alan oranının artacağını bildirmiştir.

Bartın Kent Ormanını karbon tutma, oksijen üretimi ve rekreasyonel açıdan değerlendiren Durkaya vd. (2016) ise Bartın Kent Ormanının atmosferden eksilttiği karbon miktarı ve ürettiği oksijen miktarı ile sağladığı faydayı somut bir şekilde ortaya koyarak kent ormanlarını koruyarak faydalanma esasına göre gelecek nesillere ulaştırmak zorunda olduğumuz miraslar olarak ifade etmişlerdir.

Sonuç olarak, Bartın Kent Ormanı içerisinde yer alan taksonların gerek biyoçeşitlilik gerekse oksijen üretimi için büyük önem taşımakta olup sürdürülebilir kullanım açısından koruma kullanma dengesinin gözetilmesi gerektiği sonucuna ulaşılmıştır. 


\section{Kaynaklar}

1. Aktaş, U. (2006). Kastamonu-Bartın Küre Dağlarının Milli Parkının Bartın İl Sınırları İçerisinde Kalan Bölümünün Odunsu Florası. Yüksek Lisans Tezi, ZKÜ Fen Bilimleri Enstitüsü, 90 s.

2. Anonim (2018) ). T.C. Orman ve Su İșleri Bakanlığı, Meteoroloji Genel Müdürlüğü

3. Atmış, E, Günşen, H.B. (2015). Kent Yaşamında Önemi Anlaşılmayan Bir Değer: Kent Ormanları. I Uluslararası Kent Araştırmaları Kongresi Bildiriler Kitabı,ss. 246-265. 16-17 Nisan 2015, Eskişehir.

4. Asan, Ü. (2015). Ormancılık Bilgisi, İ.Ü. Orman Fakültesi (Basımda).

5. Aydın, P. (2005). Bartın İnkumu, Güzelcehisar ve Mugada Kıyılarında Yetişen Kumul Bitkilerin Saptanması. Yüksek Lisans Tezi (yayımlanmamış). ZKÜ Fen Bilimleri Enstitüsü, Peyzaj Mimarlığı Ana Bilim Dalı, $170 \mathrm{~s}$.

6. Başaran, S. (1999 a). Kirazlık (Bartın) Barajı Florası. Doktora Tezi (yayımlanmamış). ZKÜ Fen Bilimleri Enstitüsü, Orman Mühendisliği Ana Bilim Dalı.

7. Başaran, S. (1999 b). Bartın Yöresinde Yetişen Bazı Bitkilerin Kullanım Değerleri, I International Symposium on Protection Of Natural Environment and Ehrami Karaçam 23-25 September 1999, p:863867, Kütahya, Türkiye.

8. Başaran, M.S., Adıgüzel, N. (2001). Bolu, Bartın ve Zonguldak İlleri Fındık Bahçelerinin Florasının Tespiti. Bitki Koruma Bült., 41(1-2):39-66.

9. Davis, P.H. (1965-1985). Flora of Turkey and the East Aegean Islands, Edinburgh Univ. Press, Vol:1-9.

10. Davis, P.H, Mill, R.R., Tan, K. (1988). Flora of Turkey and the East Aegean Islands, Suplement Vol.10, Edinburgh University Press. Edinburg.

11. Durkaya, B., Bekçi, B., Varol, T. (2016). Bartın Kent Ormanının Karbon Tutma, Oksijen Üretimi ve Rekreasyonel Açıdan Değerlendirilmesi. Kastamonu Uni., Orman Fakültesi Dergisi, 2016, 16 (1): 111119.

12. Ekici, B. (2010). Bartın Kenti ve Yakın Çevresinde Yetişen Bazı Doğal Bitkilerin Kentsel Mekanlarda Kullanım Olanakları, Süleyman Demirel Üniversitesi Orman Fakültesi Dergisi, 2:110-126.

13. Ekim, T., Koyuncu, M., Vural, M., Duman, H., Aytaç, Z., Adıgüzel, N. (2000). Türkiye Bitkileri Kırmızı Kitabı (Eğrelti ve Tohumlu Bitkiler), ISBN 975-93611-0-8.

14. Güner, A., Özhatay, N., Ekim, T., Başer, K.H.C. (2000). Flora of Turkey and the East Aegean Islands, Vol:11,Edinburgh University Press.Edinburg, 656 pp.

15. Güner, A., Aslan, S., Ekim, T., Vural, M., Babaç, M.T. (Ed.) (2012). Türkiye Bitkileri Listesi (Damarlı Bitkiler). Nezahat Gökyiğit Botanik Bahçesi ve Flora Araştırmaları Derneği Yayını. İstanbul.

16. İmal, B., Öner, N., Sıvacıŏ̆lu, A., Ayan, S. (2007). Kent Ormancılığı Olgusu ve Türkiye'deki Kent Ormanları. Ulusal Çevre Sempozyumu, Bildiriler Kitabı (CD), 12 s., 18-21 Nisan, Mersin.

17. Kaya, Z., Başaran, S. (2006). Bartın Florasına Katkılar. Gazi Üniv.Orman Fak.Derg. Cilt:6 No:1 4062.

18. Kaya, Z., Yaman, B. (2017). Bartın İlinin Karasal ve İç Su Ekosistemleri Biyolojik Çeşitlilik Envanter ve İzleme Projesi (Flora Bölümü). Orman ve Su İşleri Bakanlığı Doğa Koruma ve Milli Parklar (DKMP) 10. Bölge Müdürlüğü Bartın İl Şube Müdürlüğü, Ankara.

19. OGM (2005). Ormancılığımızda yeni Yaklaşım "Kent Ormancılığı”. T.C. Çevre ve Orman Bakanlığı, Orman Genel Müdürlüğü.

20. Öztürk, M., Bolat, İ. (2014). Transforming pinus pinaster forest to recreation site: preliminary effects on la1, some forest floor, and soil properties. Environ Monit Assess.186:2563-2572.

21. Palta, Ş. (2012). Bartın Yöresi Çayır-Mera Alanlarında Bulunan Gramineae Familyasına Ait Bitkilerde Arbusküler Mikorizal Fungusların (amf) Varlığının ve Ekolojik Özelliklerinin Belirlenmesi. Doktora Tezi BÜ Fen Bilimleri Enstitüsü $171 \mathrm{~s}$.

22. Palta, Ş., Genç Lermi, A. (2017). Bartın İli Kent Ormanı Alt Florasındaki Otsu Bitkilerin Bazı Özelliklerinin Belirlenmesi . ÇOMÜ Zir. Fak. Dergisi, 2017: 5 (2): 1-8.

23. Sarı Nayim, Y. (2010). Amasra-İnkum (Bartın) arasında yeralan önemli biyotopların haritalanması. Doktora Tezi, İstanbul Üniversitesi Fen Bilimleri Enstitüsü, İstanbul.

24. Sarı Nayim, Y., Ayaşlıgil, Y. (2015). Contributions to the Flora between Amasra and İnkum (Bartın) located in Western Black Sea Region. Biological Diversity and Conservation, Vol.8, Sayı 3, Eskişehir.

25. Sarı Nayim, Y. (2017). Mapping of Biotopes Between Amasra and İnkum (Bartın), Western Black Sea Regon of Turkey. Journal of Environmental Biology, 2017(38), 1033-1042.

26. Sarıbaş, M., Kaya, Z., Başaran, S., Yaman, B. (1999). Batı Karadeniz Bölgesi'nde Doğal Olarak Yetişebilen Bitkilerden Peyzaj Uygulamalarında Kullanılabilecek Türlerin Belirlenmesi, TÜBİTAK projesi, TOGTAG-1685.

27. Sezik, E. (1984). Orkidelerimiz Türkiye'nin Orkideleri. Sandoz Kültür Yayınları No:6.

28. Tekebaş, S. (2017). Küre Dağları Milli Parkı'nın Bartın Bölümü’nde Bulunan Zoni Yaylası ve Etrafının Florası. Bartın Üniversitesi Fen Bilimleri Enstitüsü, Yüksek Lisans Tezi, 88 sayfa. 
29. URL-1 (2021). https://www.ogm.gov.tr/tr/ormanlarimiz/mesire-yerleri., (15.04.2021).

30. Uslu, Ş., Ayaşlıgil, T. (2007). Kent Ormanlarının Rekreasyonel Amaçlı Kullanımı ve İstanbul İli Örneğinde İrdelenmesi. Yıldız Teknik Üniversitesi Mim. Fak. E-Dergisi Cilt 2, Sayı 4.

31. Yaltırık, F. (1962). Bitki toplayıcılarına tavsiyeler. İÜ Orman Fakültesi Dergisi, Seri: A, Cilt: 12, Sayı: 2,S. 121-127, İstanbul.

32. Yaltırık, F., Akkemik, Ü. (2011). Türkiye'nin doğal gymnospermleri (açık tohumlular). Çevre ve Orman Bakanlı̆̆ 1 , Ankara, 214s.

33. Yaltırık, F., Efe, A. (1996). Otsu Bitkiler Sistematiği, İÜ Yayın No: 3940, Orman Fakültesi Yayın No: 10, İstanbul, $52 \mathrm{~s}$.

34. Yatkın, H. (1996). Amasra Yöresi Floristik Kompozisyonu. Yüksek Lisans Tezi, ZKÜ Fen Bilimleri Enstitüsü, $321 \mathrm{~s}$.

35. Yılmaz, H. (2001). Bartın kenti ve yakın çevresinde biyotopların haritalanması, Doktora Tezi, İstanbul Üniversitesi Fen Bilimleri Enstitüsü, İstanbul.Zencirkıran,M. 2013. Peyzaj Bitkileri I (Açı Tohumlu Bitkiler-Gymnospermae). 1. Basım,Nobel Akdemik Yayıncılık,Yayın No:605, Fen Bilimleri Nu:57, Ankara.475 s.

36. Zencirkıran M (2013). Peyzaj bitkileri I (Açık tohumlu bitkiler-Gymnospermae). Nobel Akademik Yayıncılık Eğitim Danışmanlık Tic. Ltd. Şti., Ankara.

\section{Ekler}

Ek 1. Bartın Kent Ormanı florasında bulunan bazı taksonların doğal yetişme ortamlarındaki görünümleri.

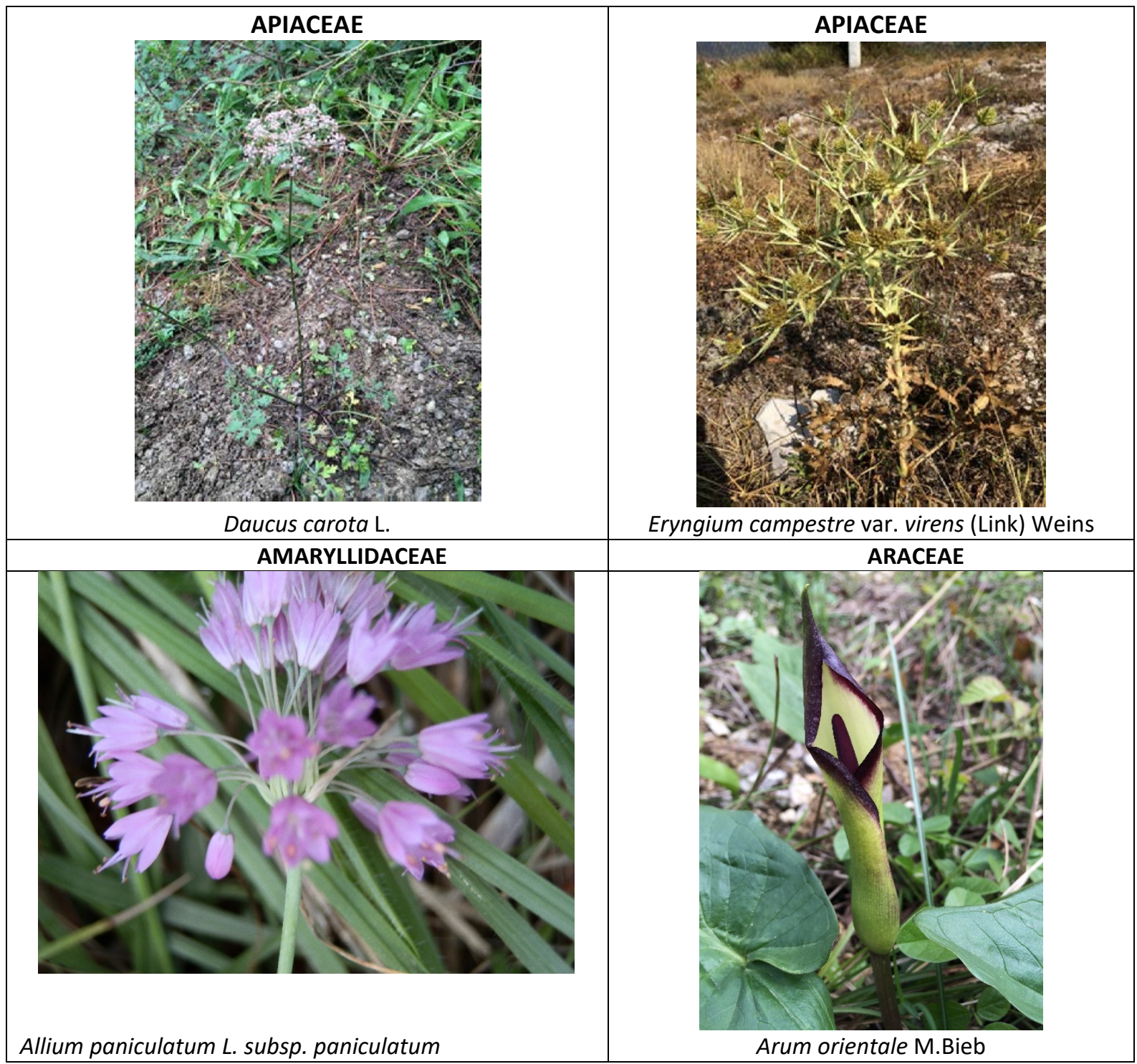




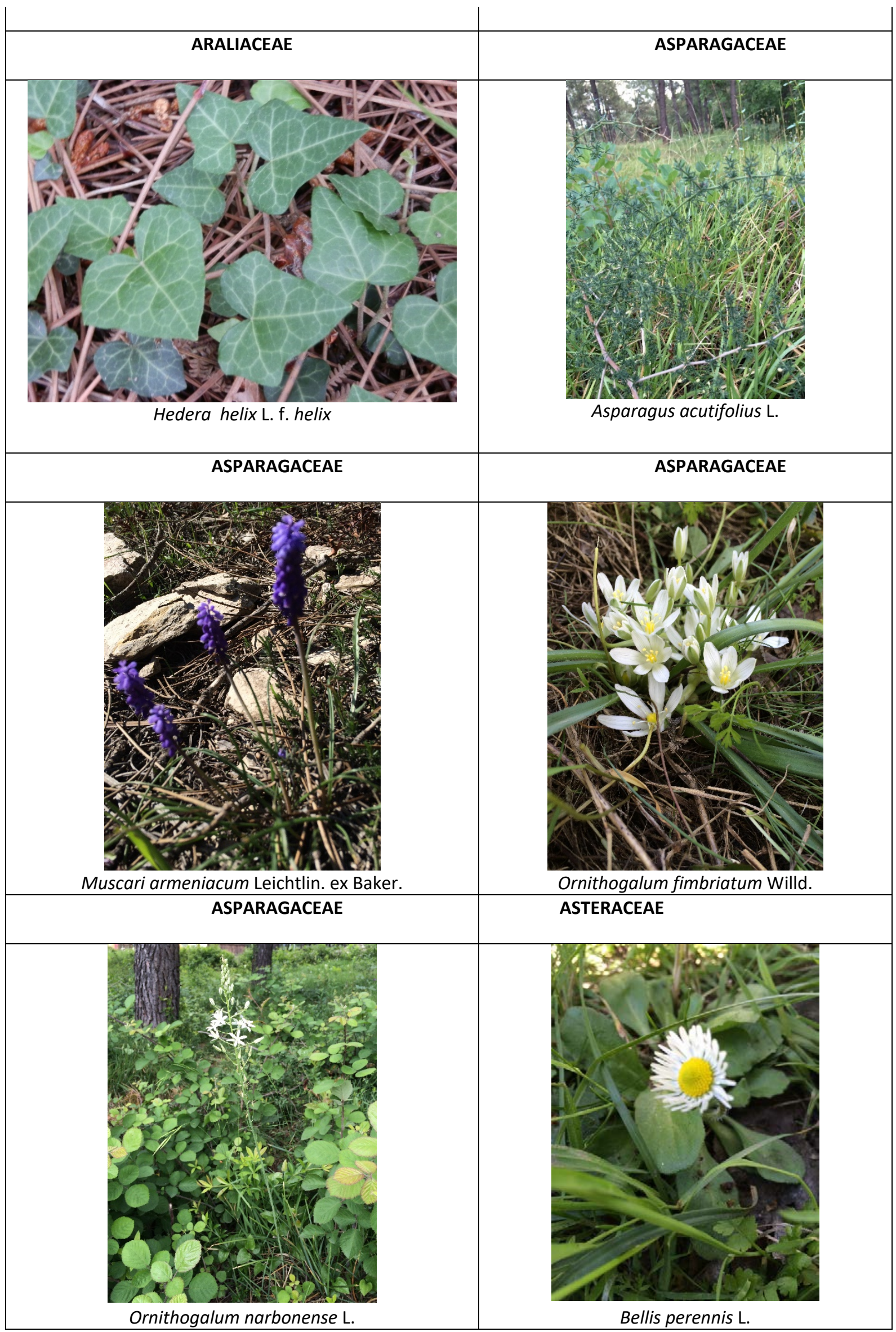




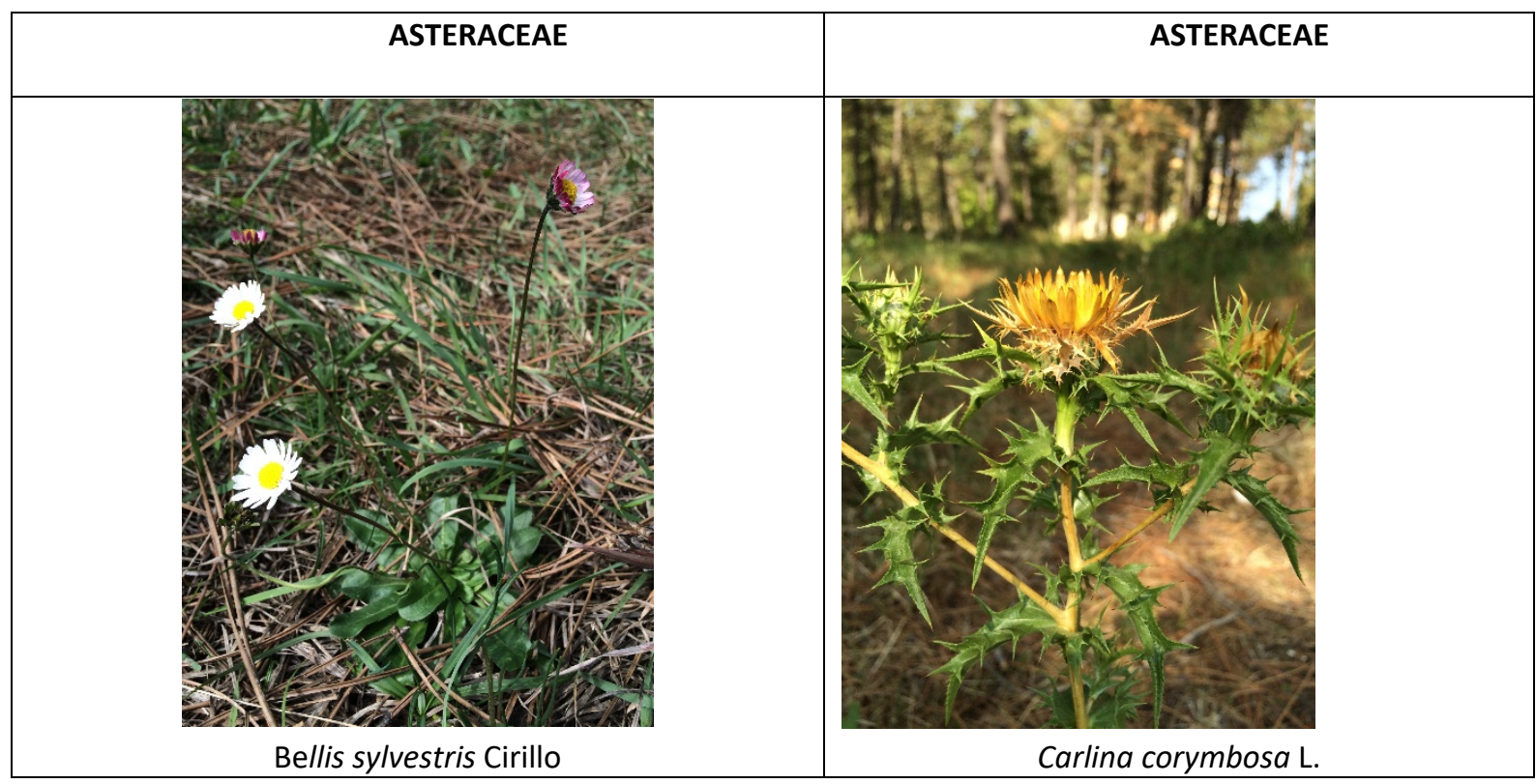

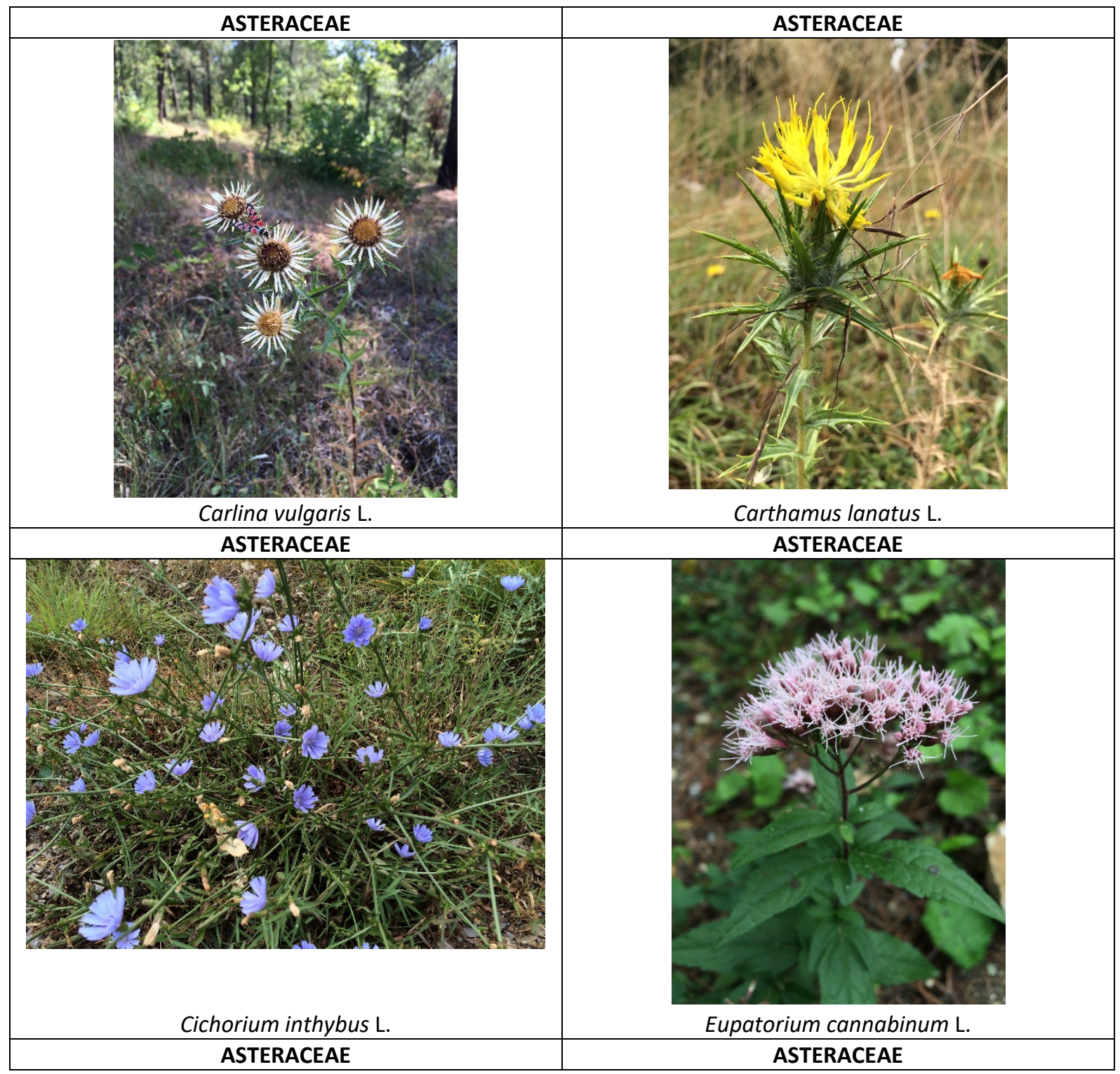




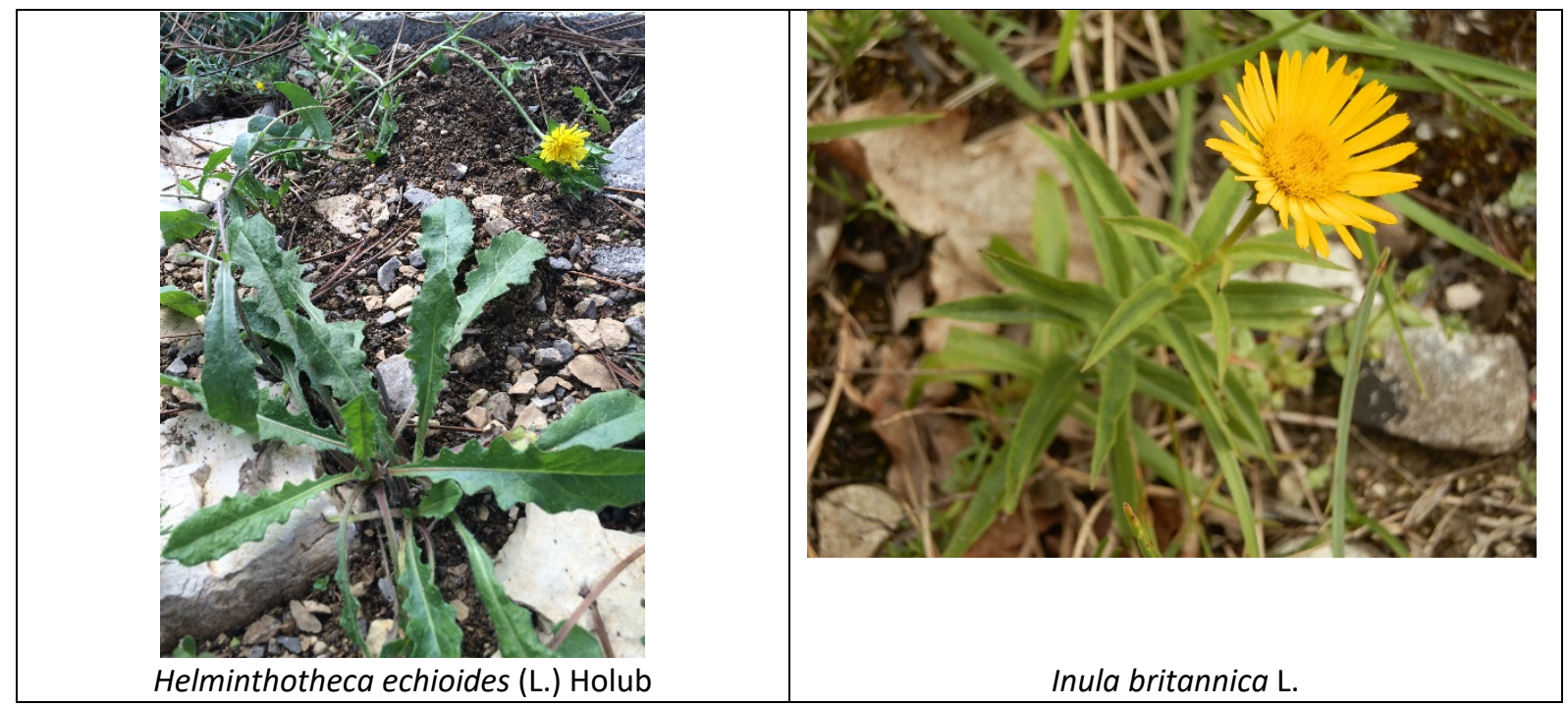

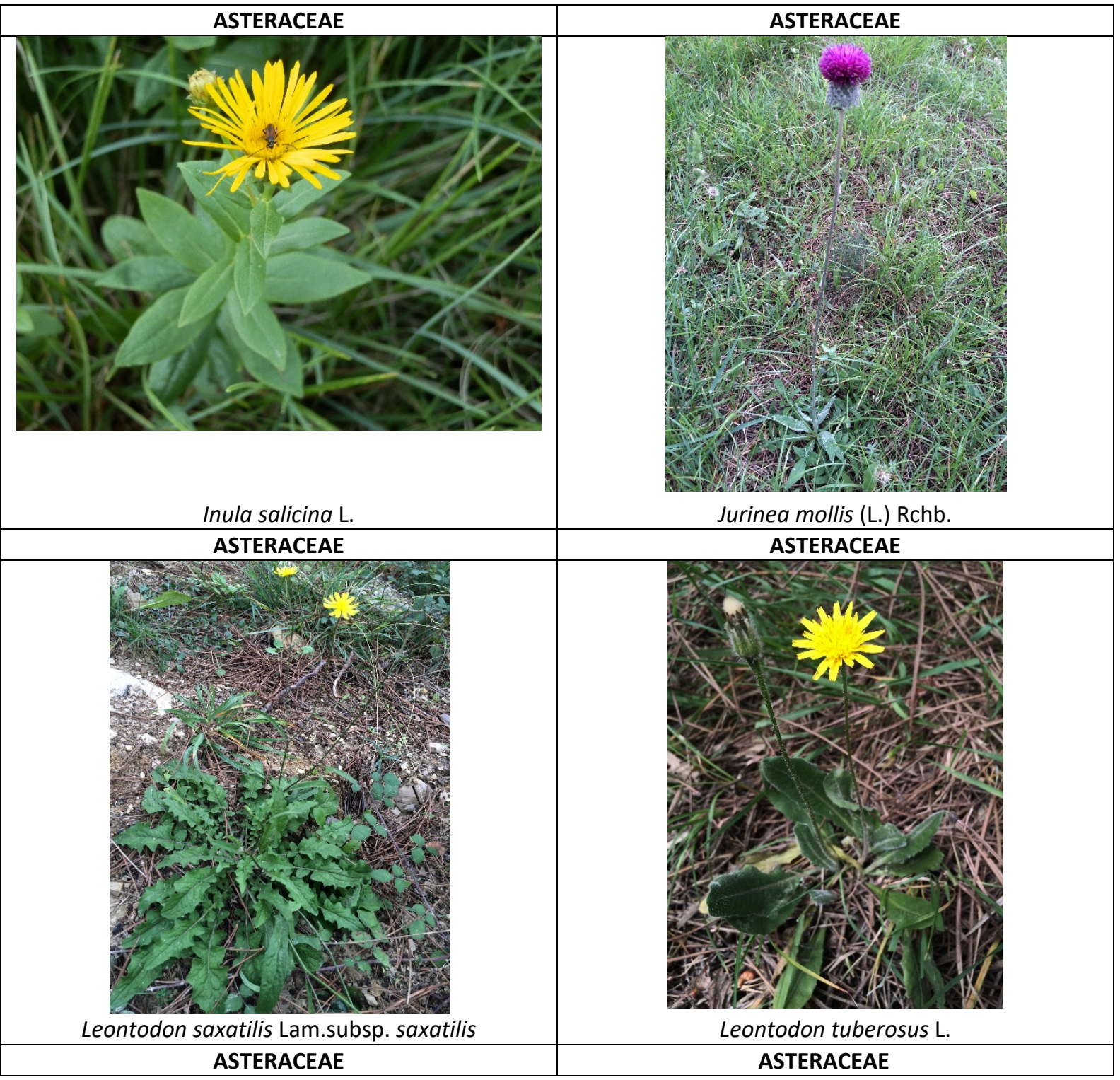




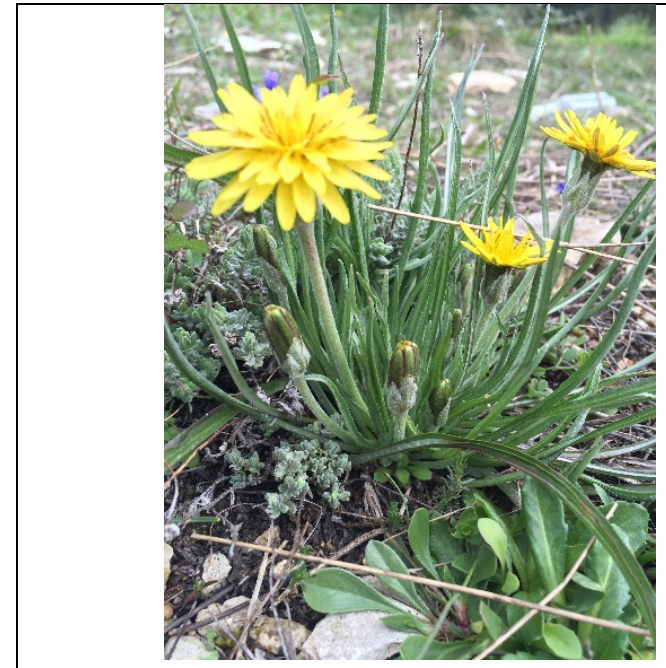

Scorzonera mollis M.Bieb.

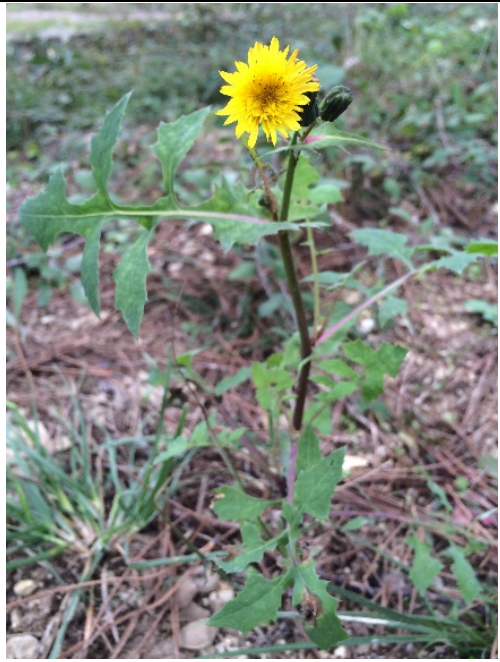

Sonchus asper (L.) Hill. subsp. glaucescens (Jord.) Ball.

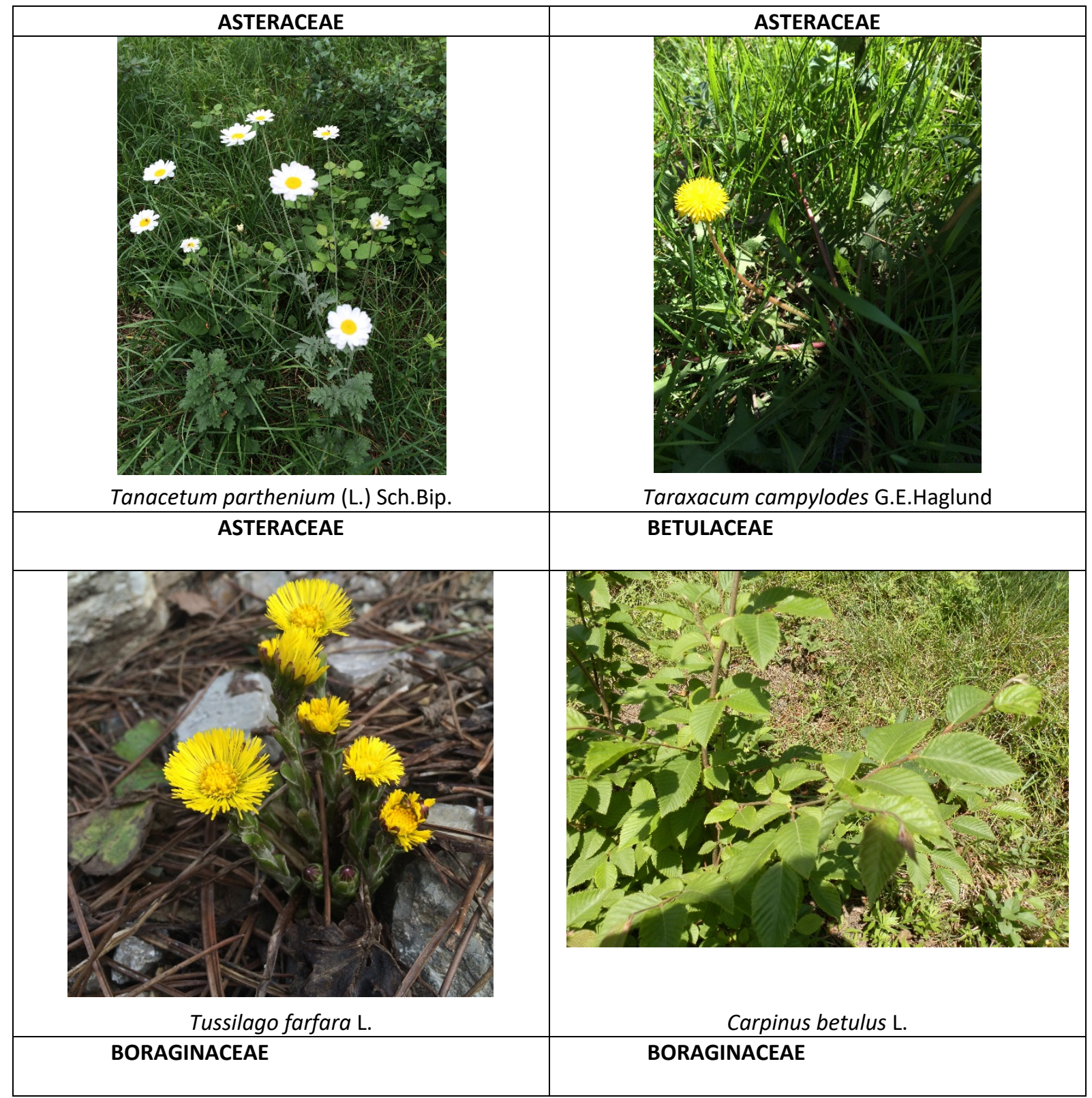




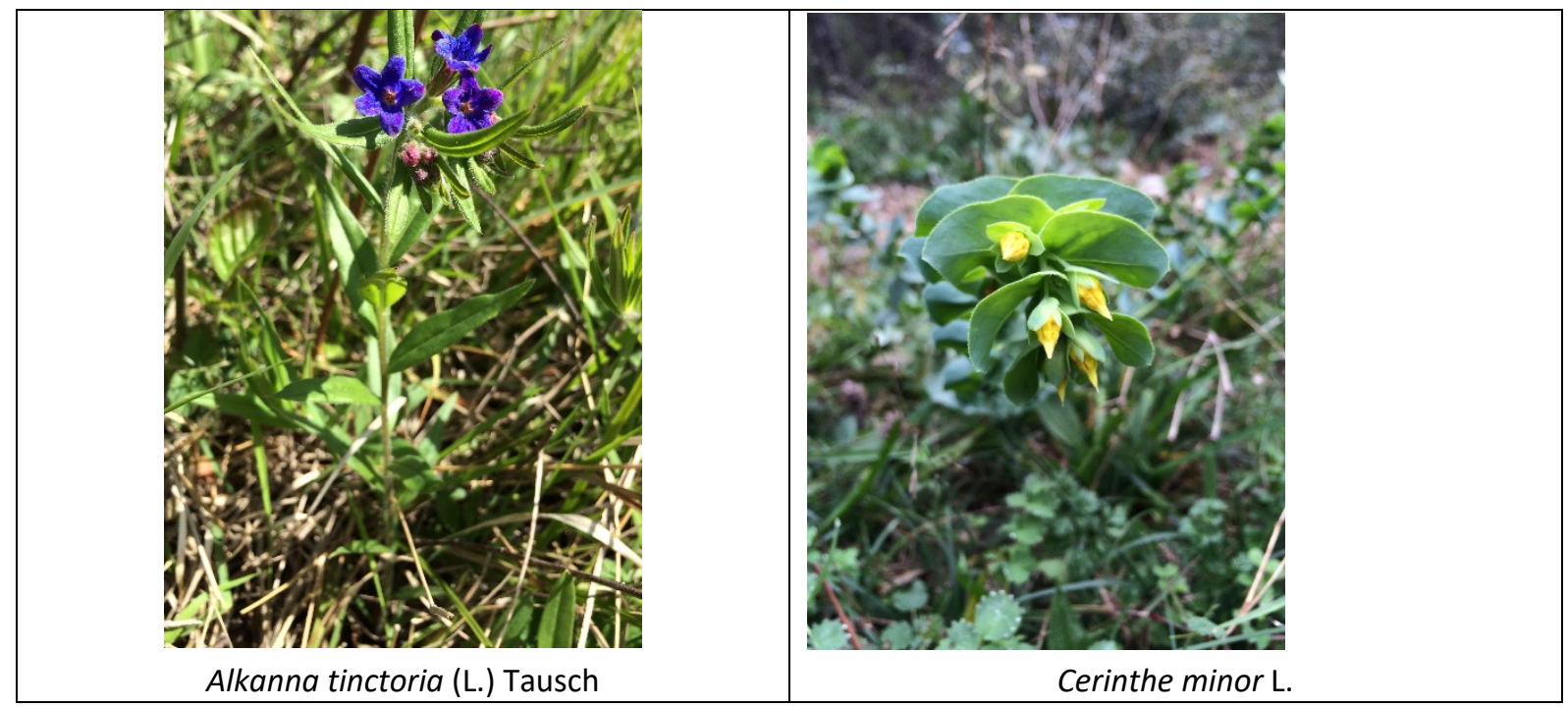

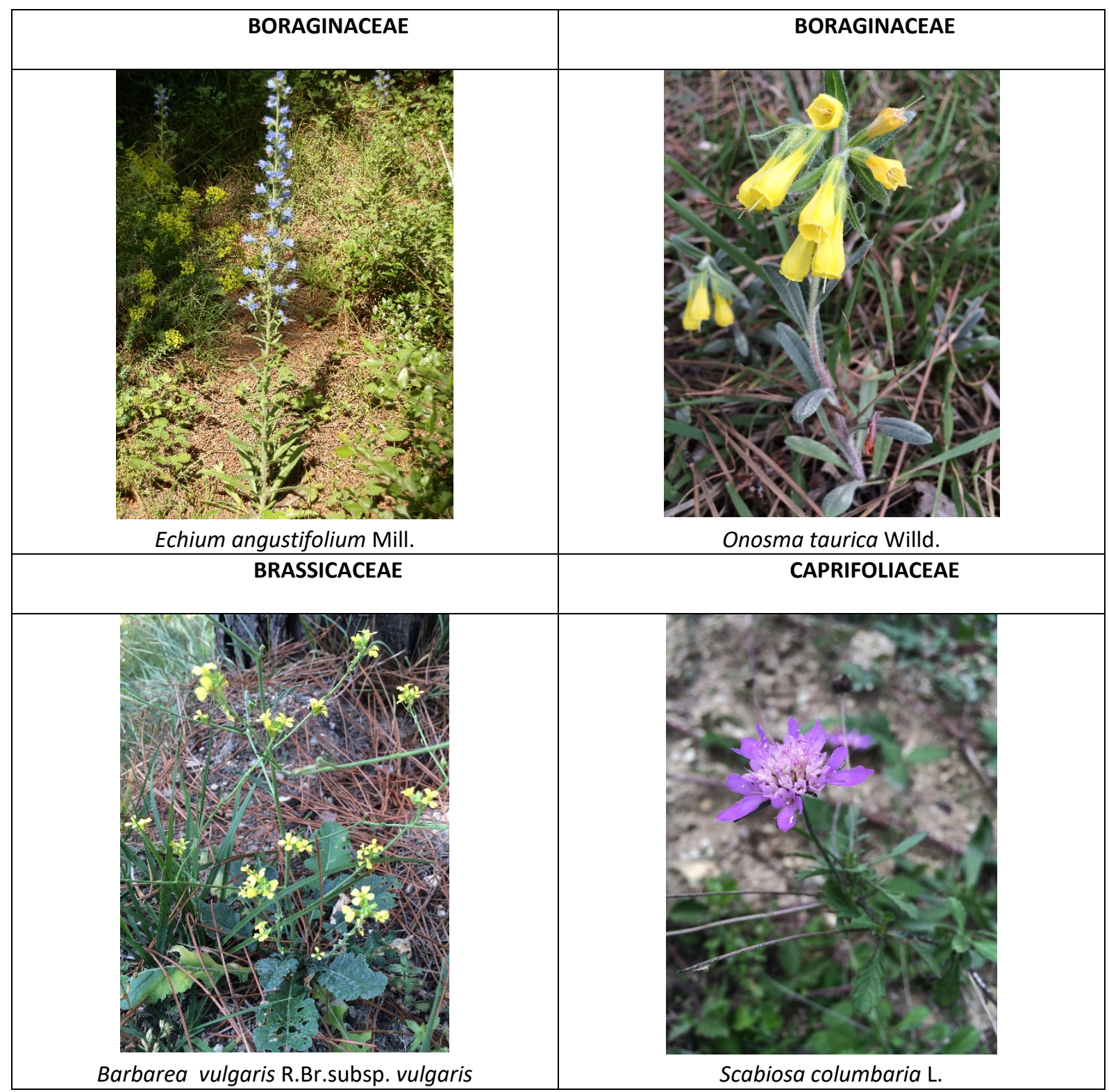




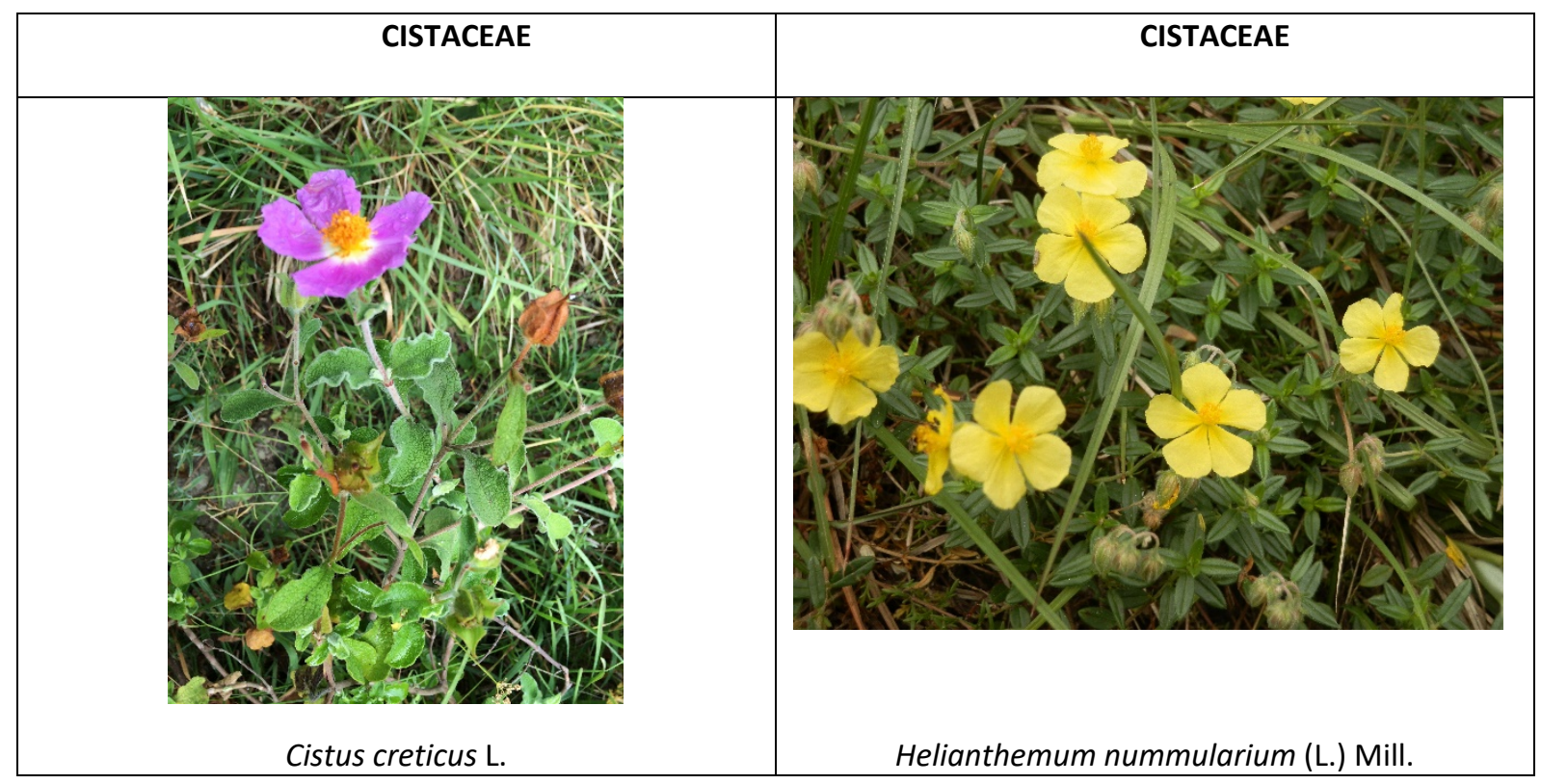

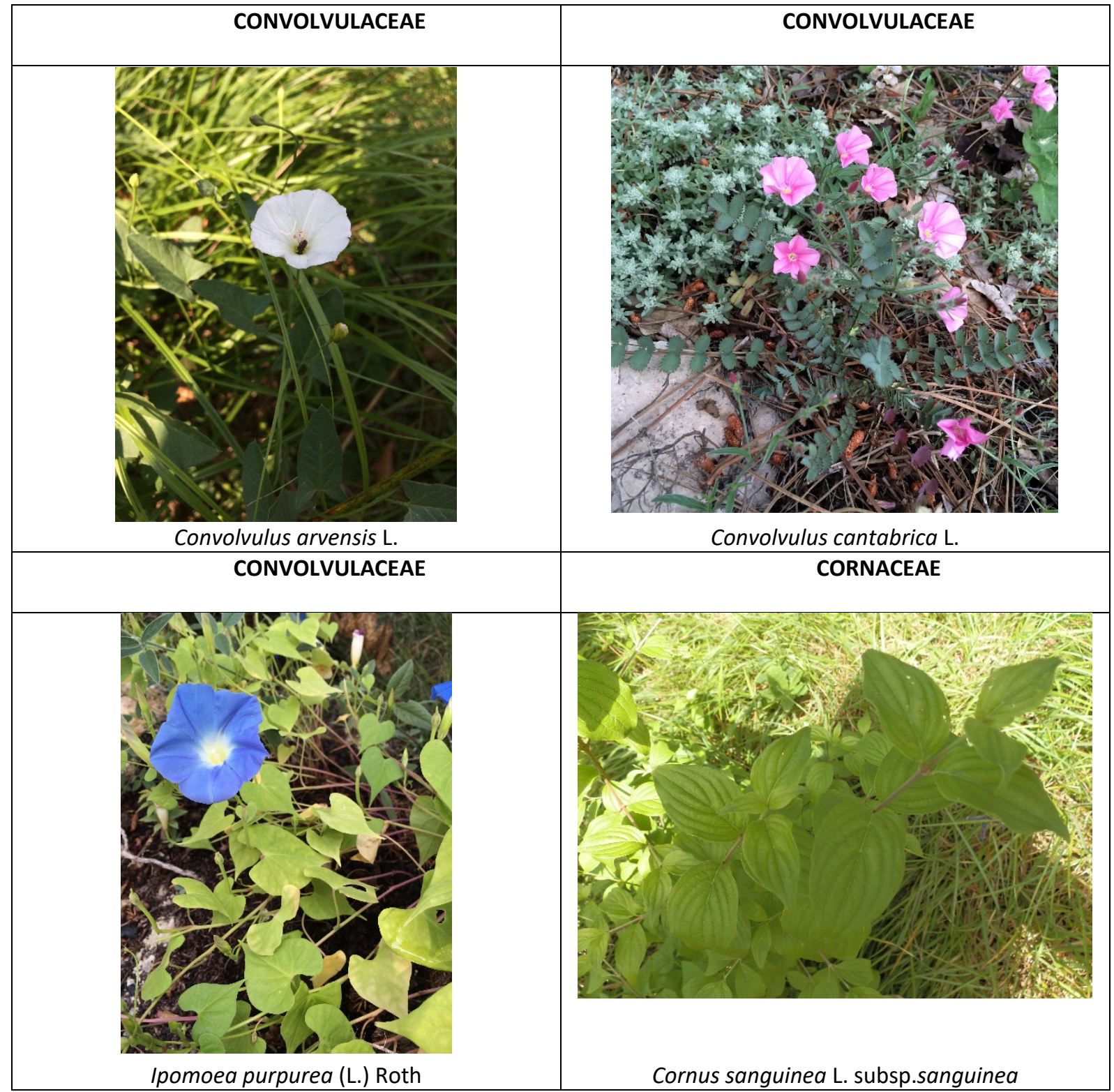




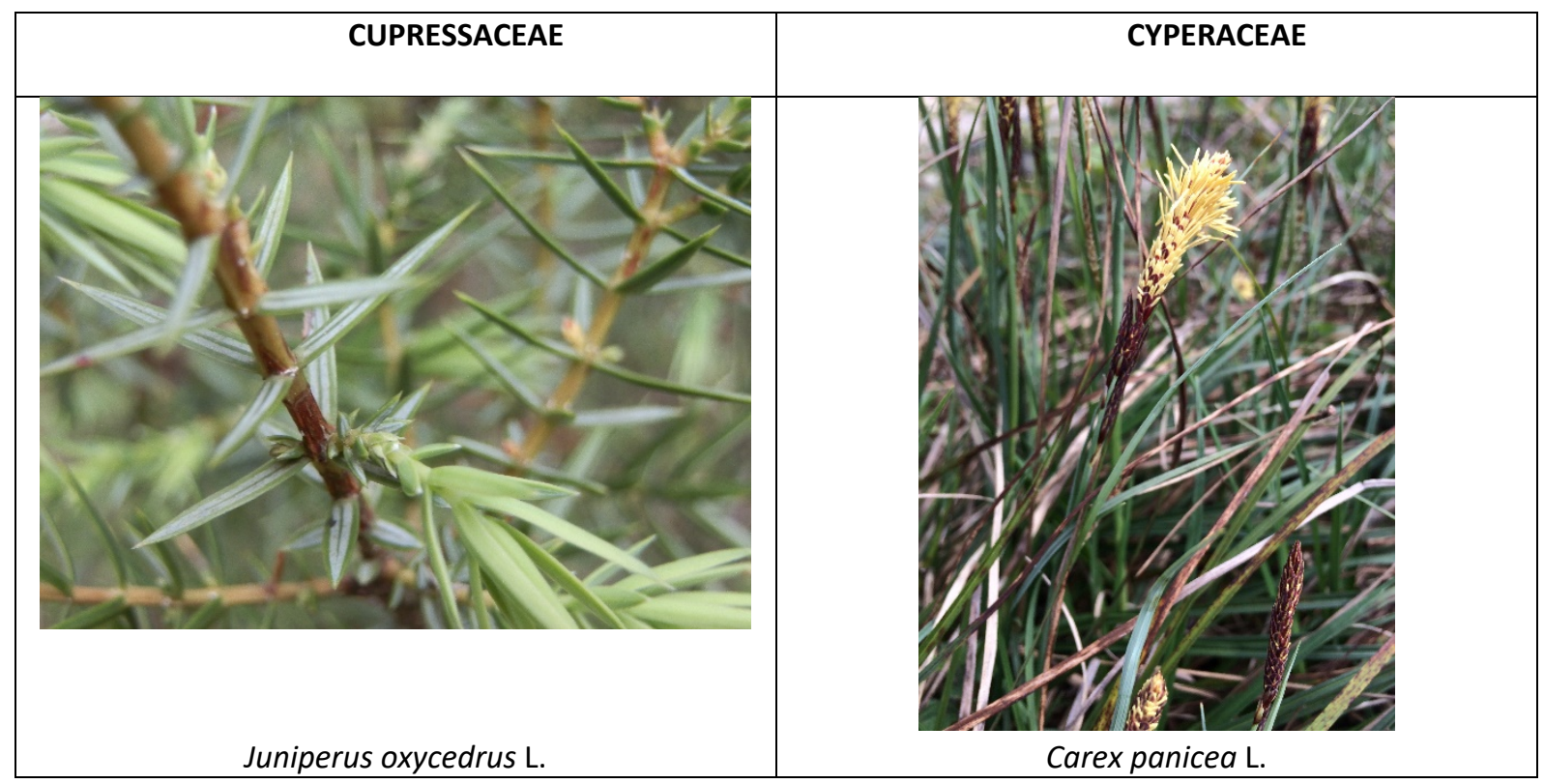

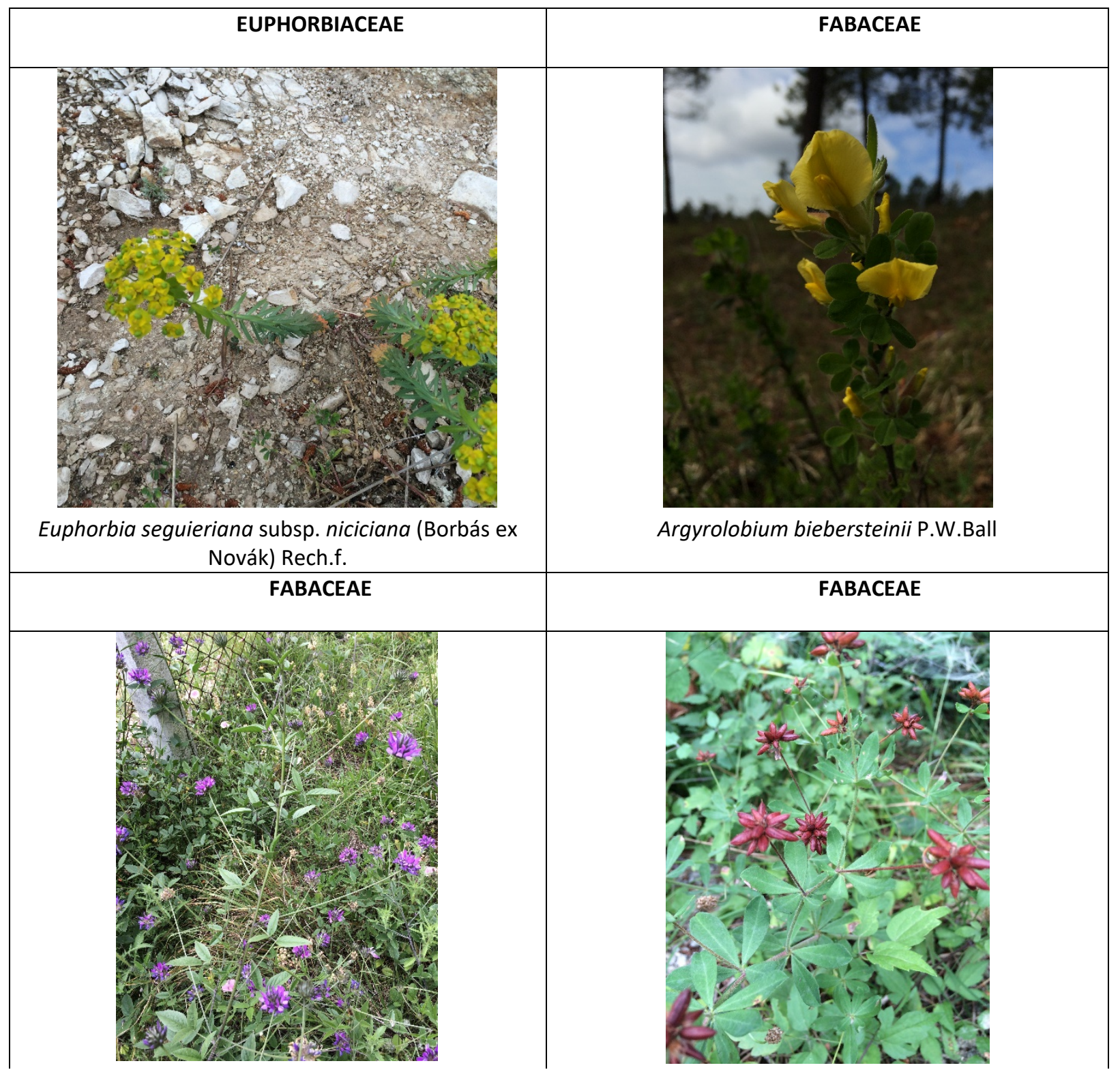




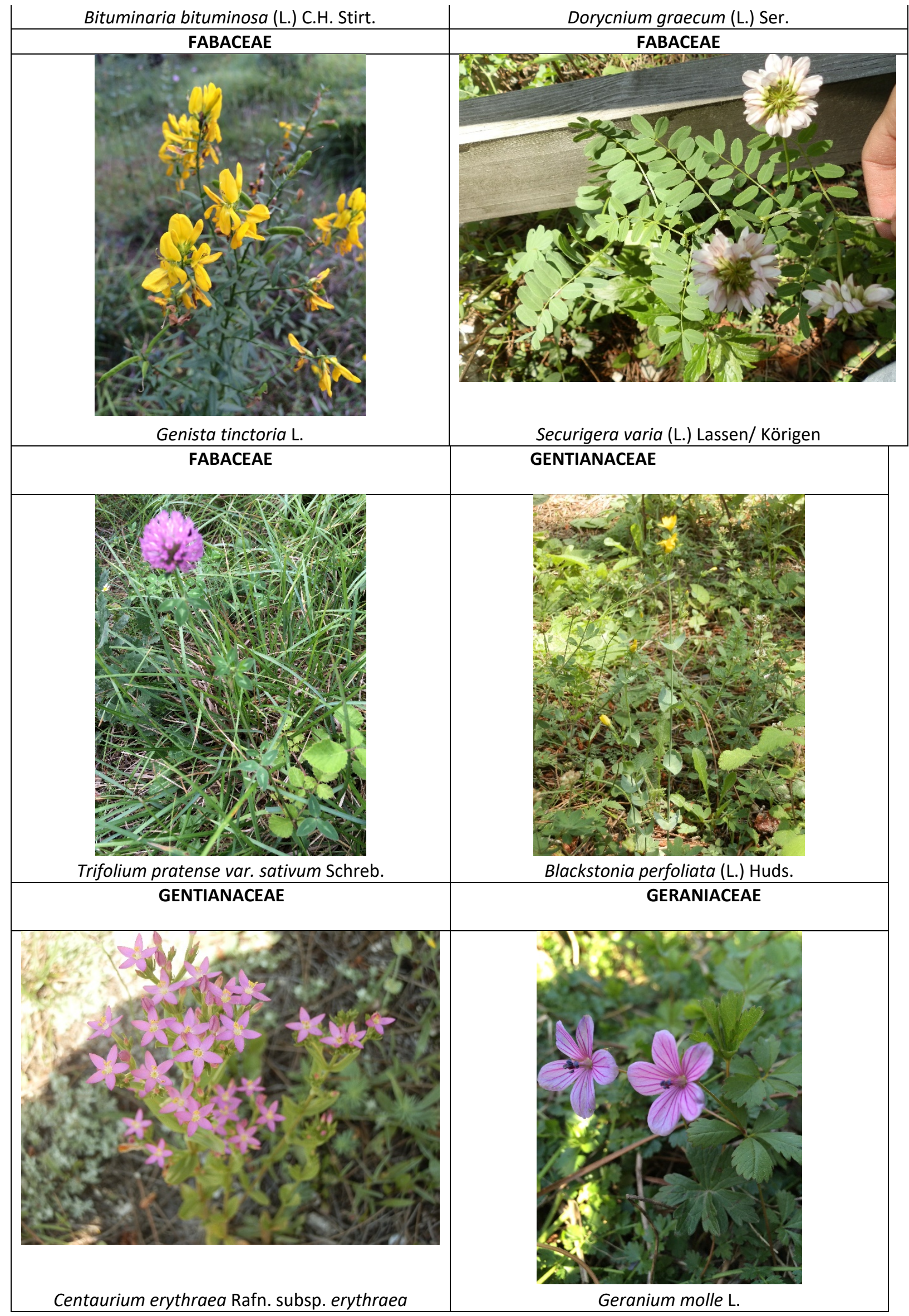




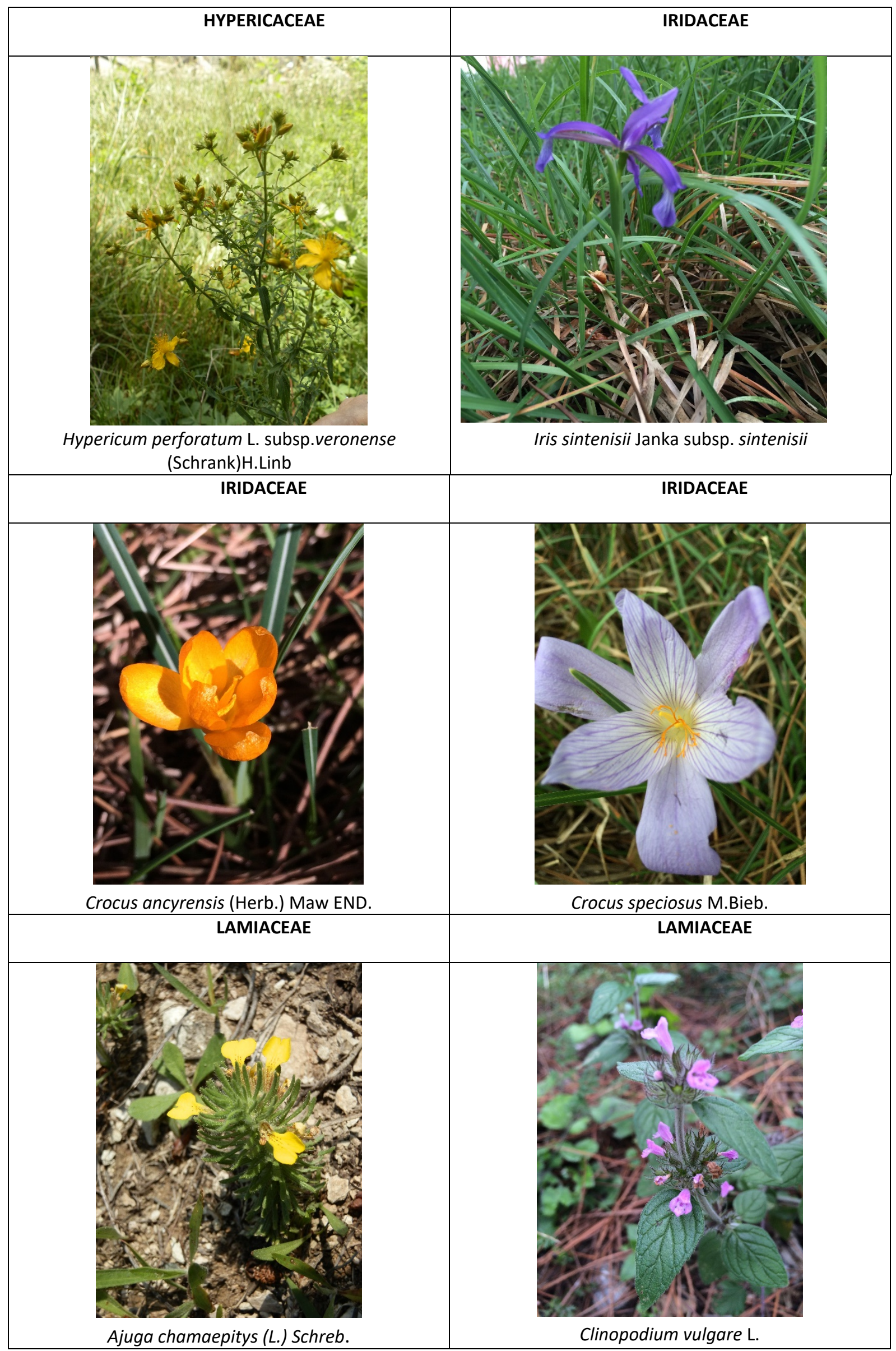




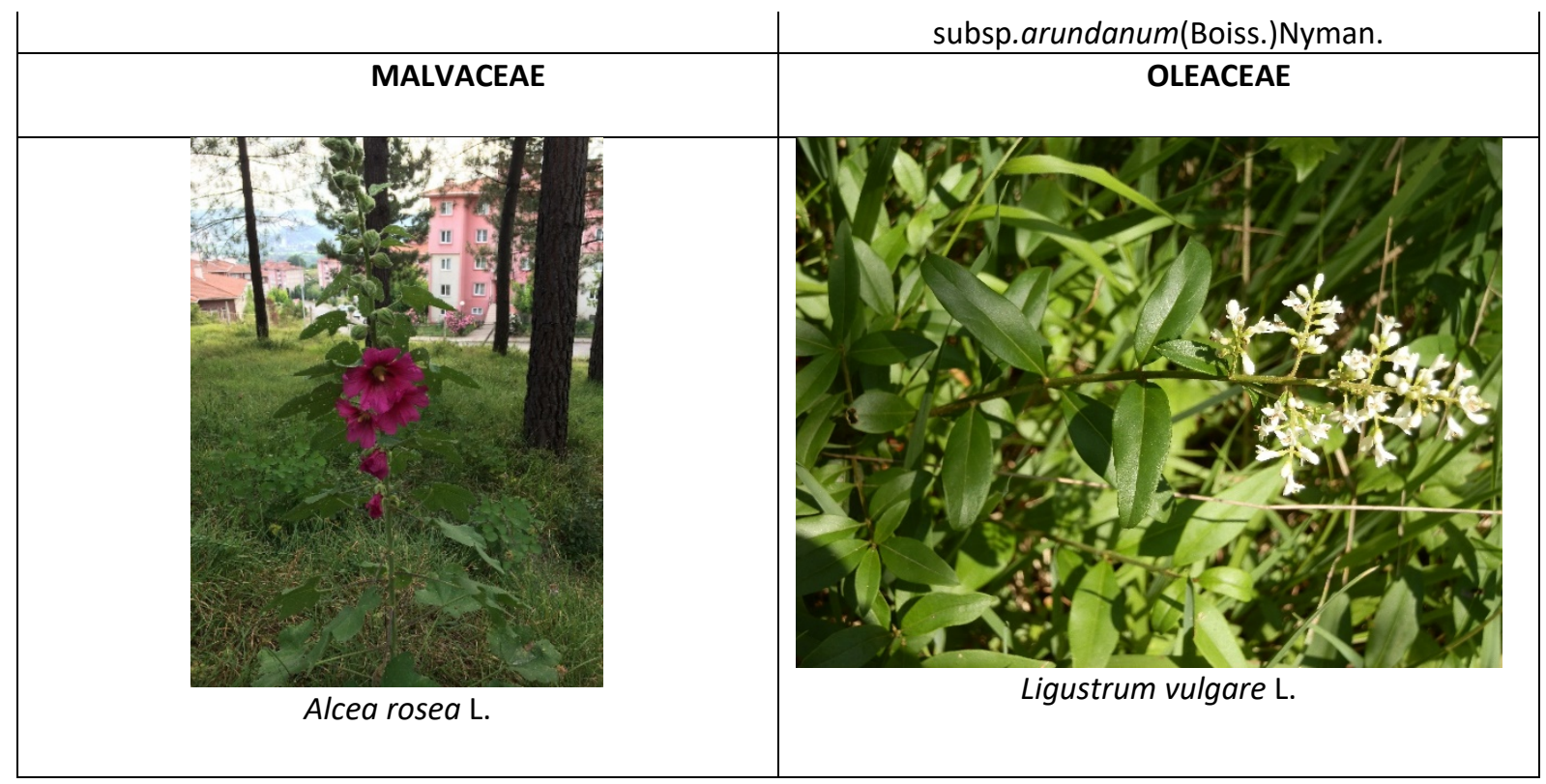

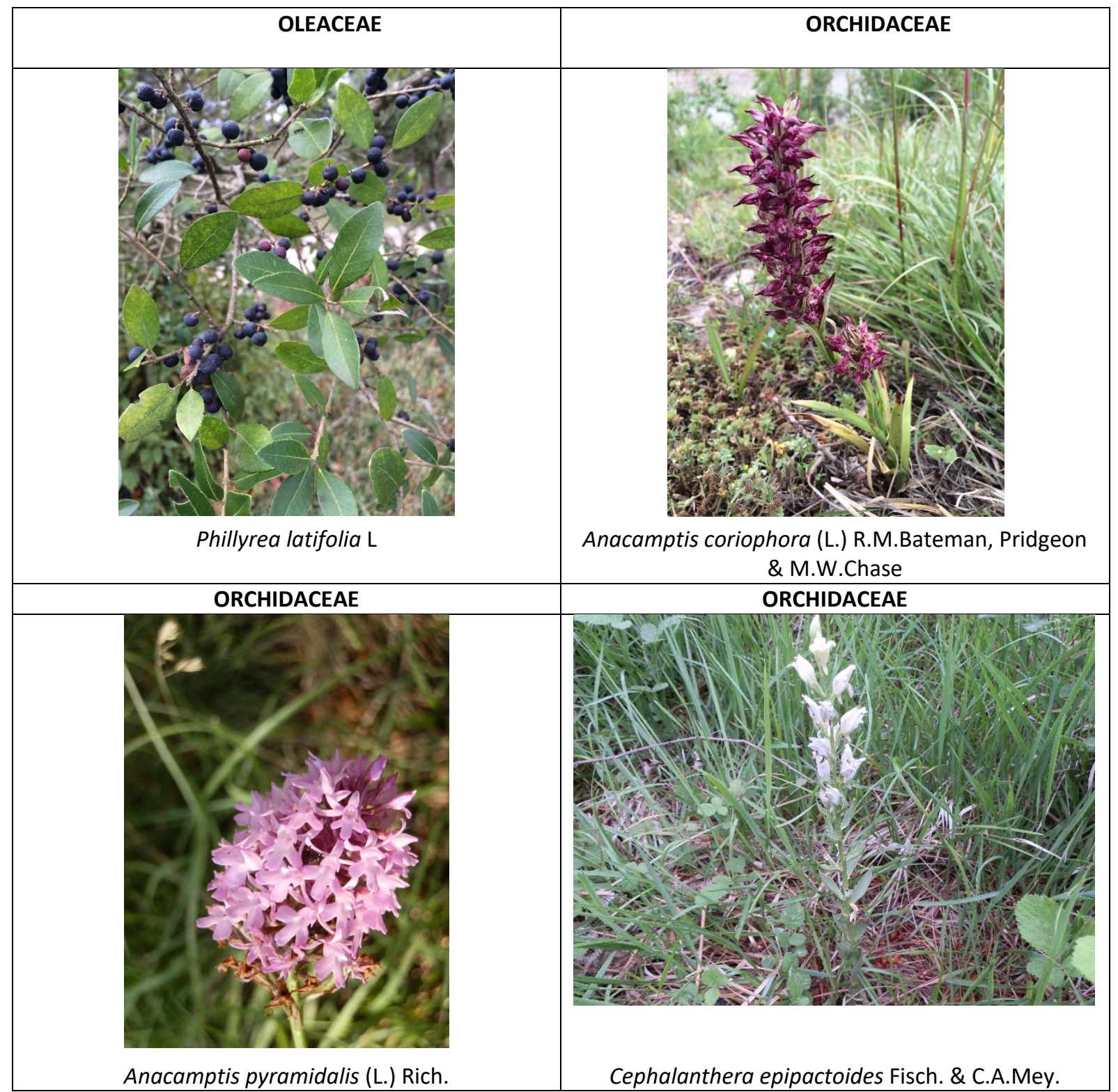




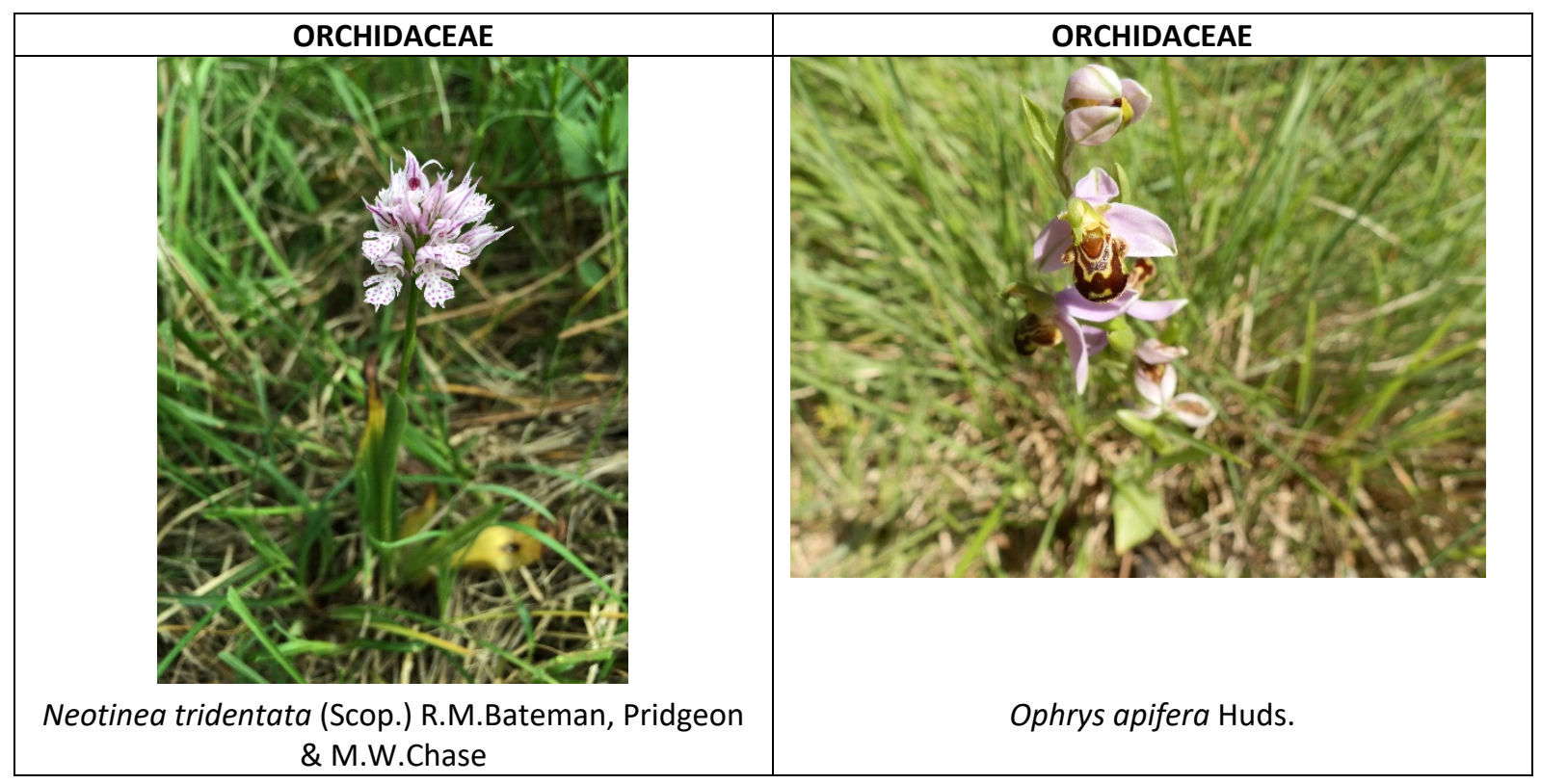

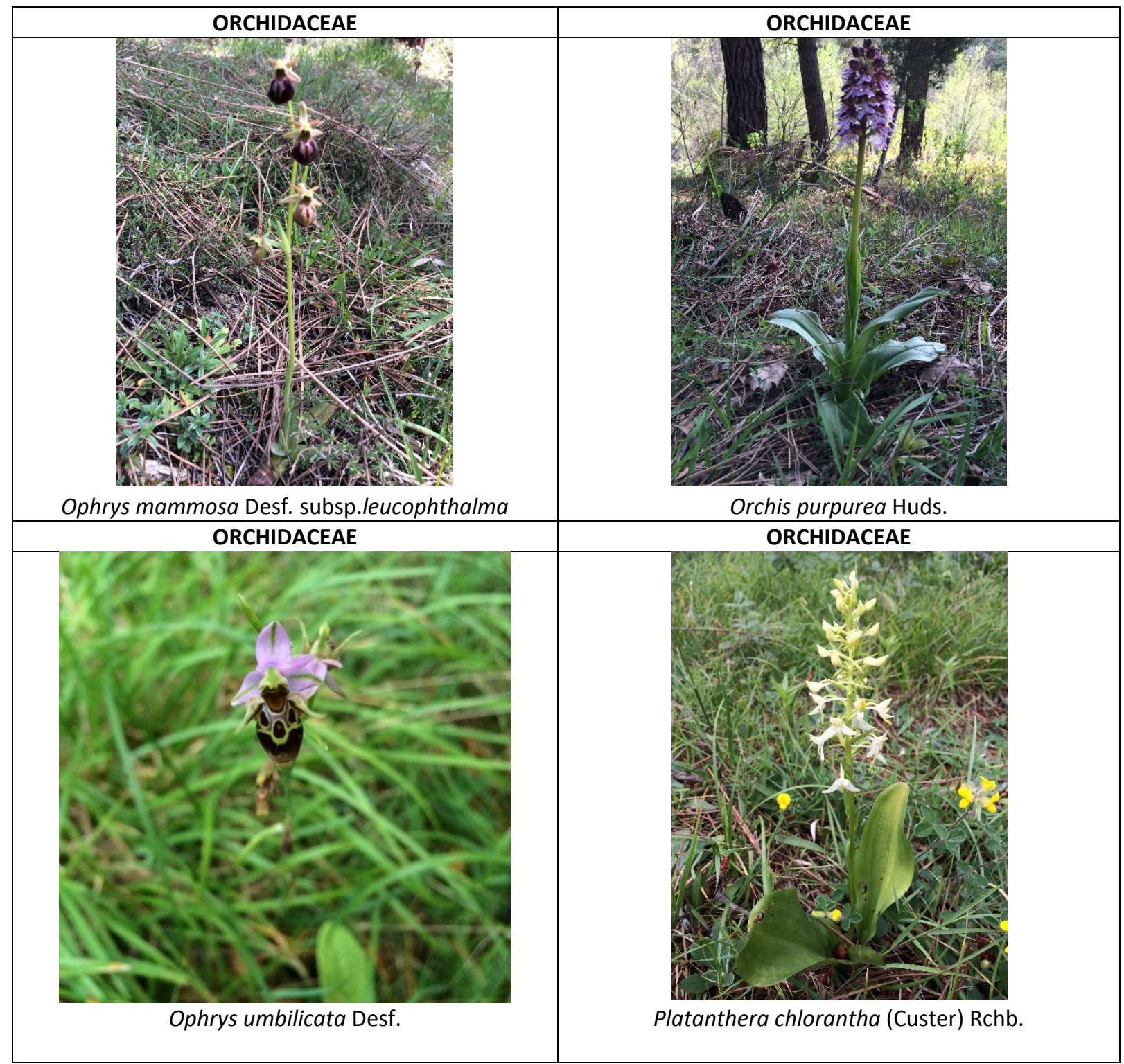




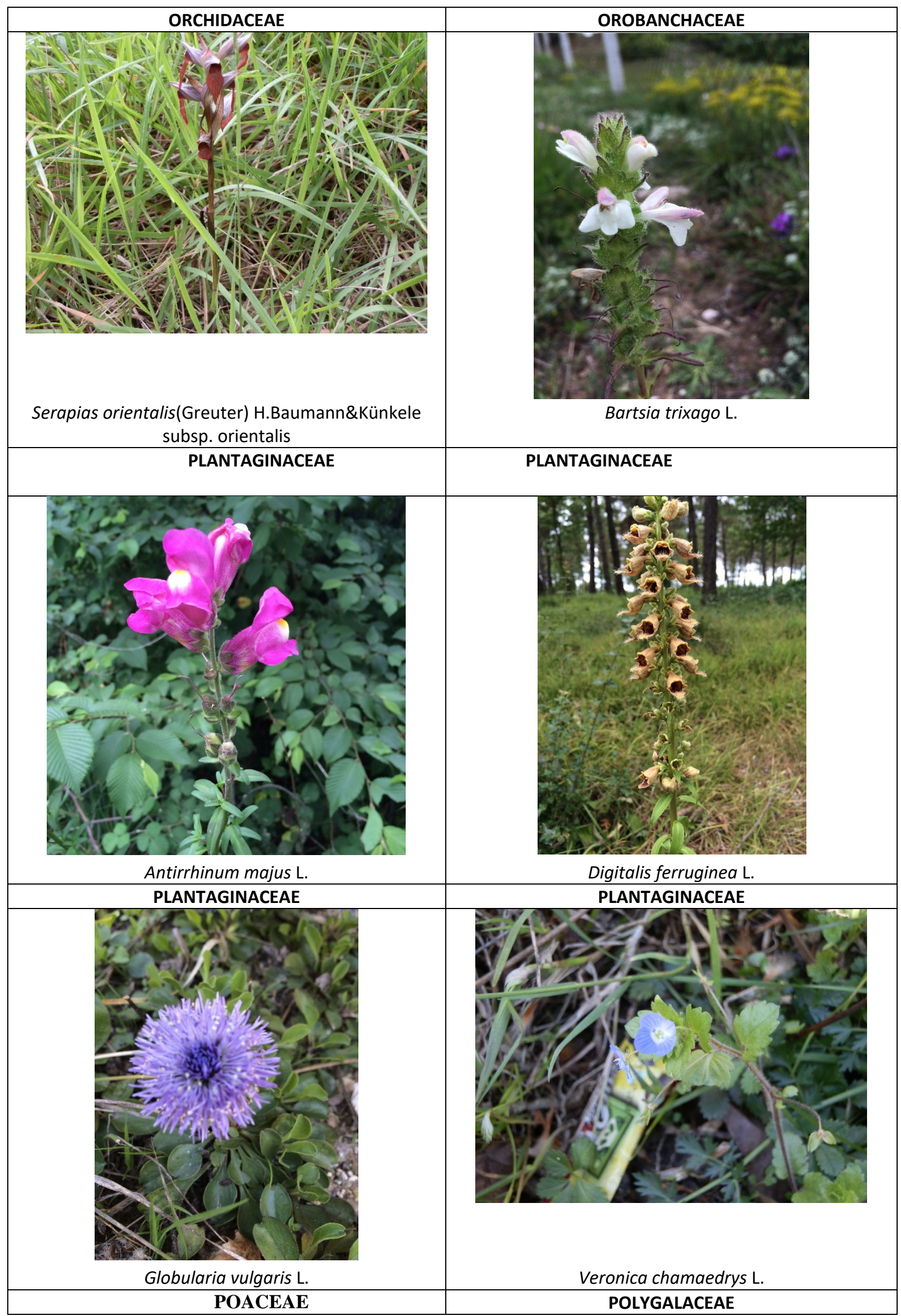



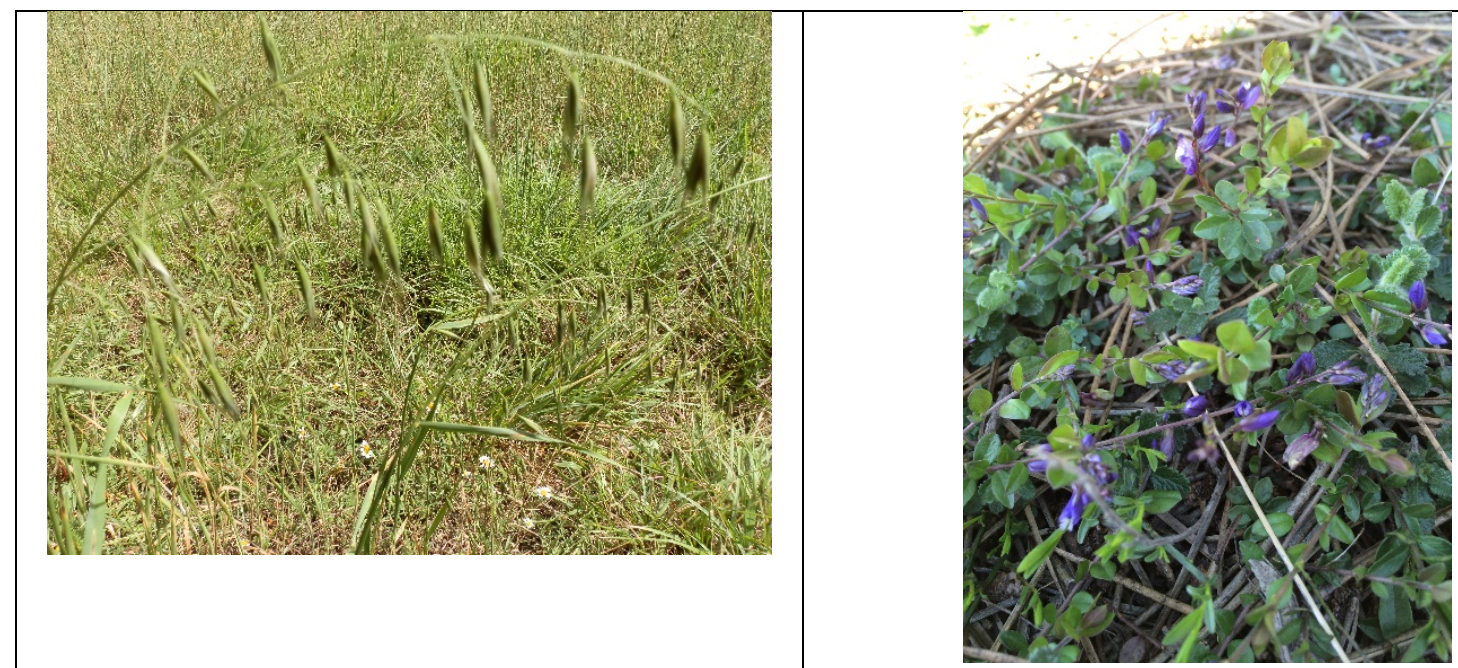

Avena barbata Pott ex Link

Polygala supina Schreb.

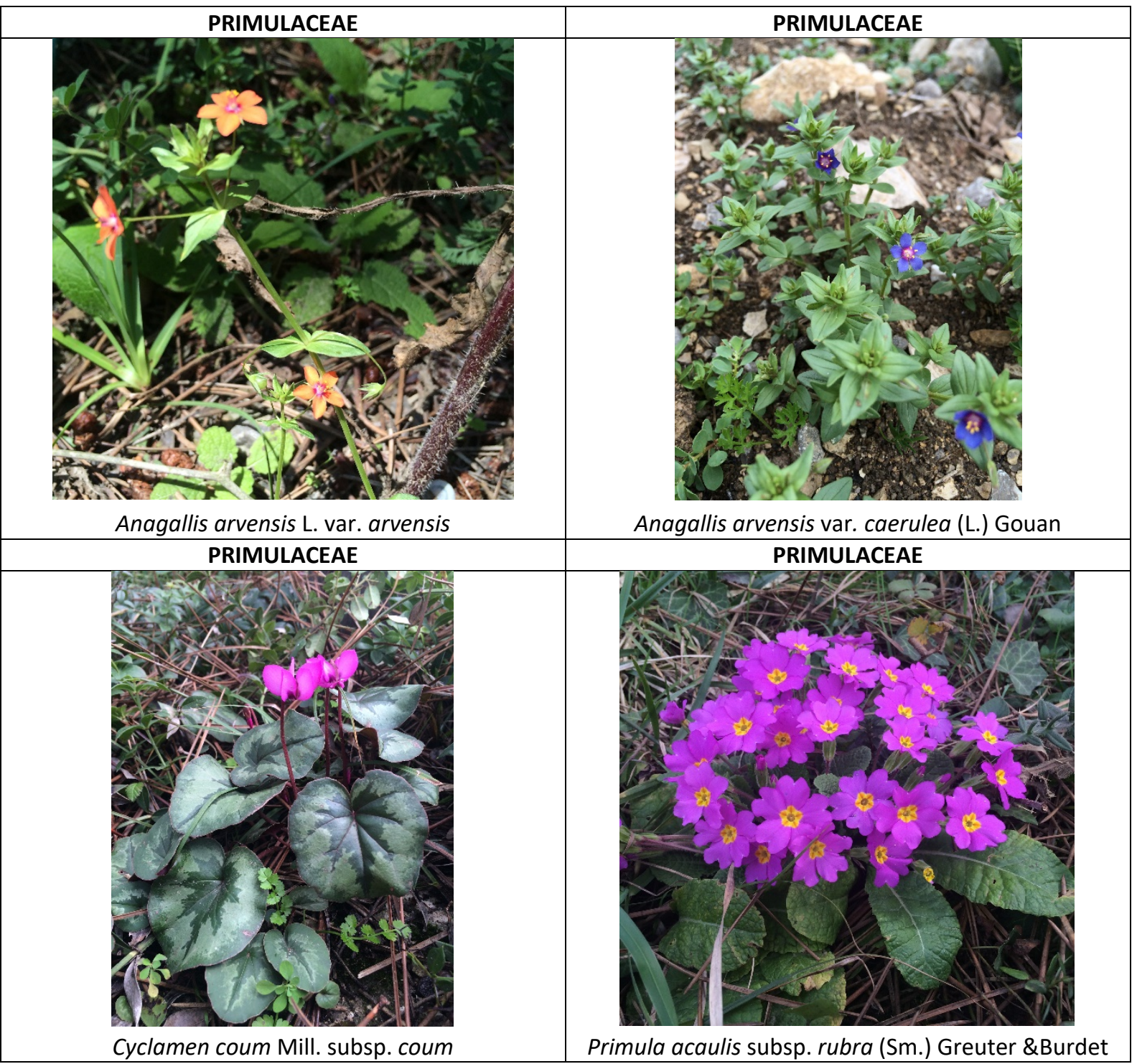




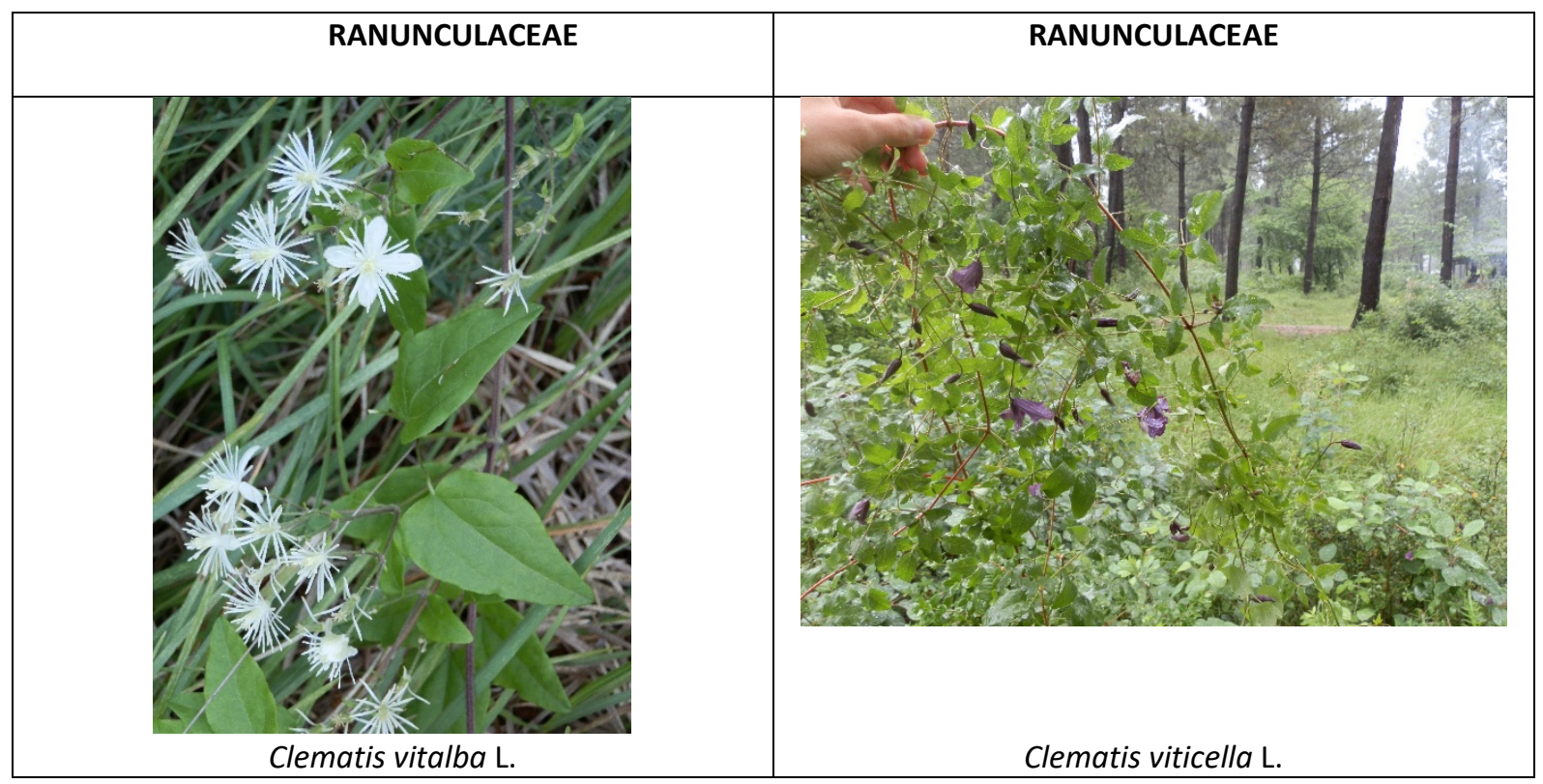

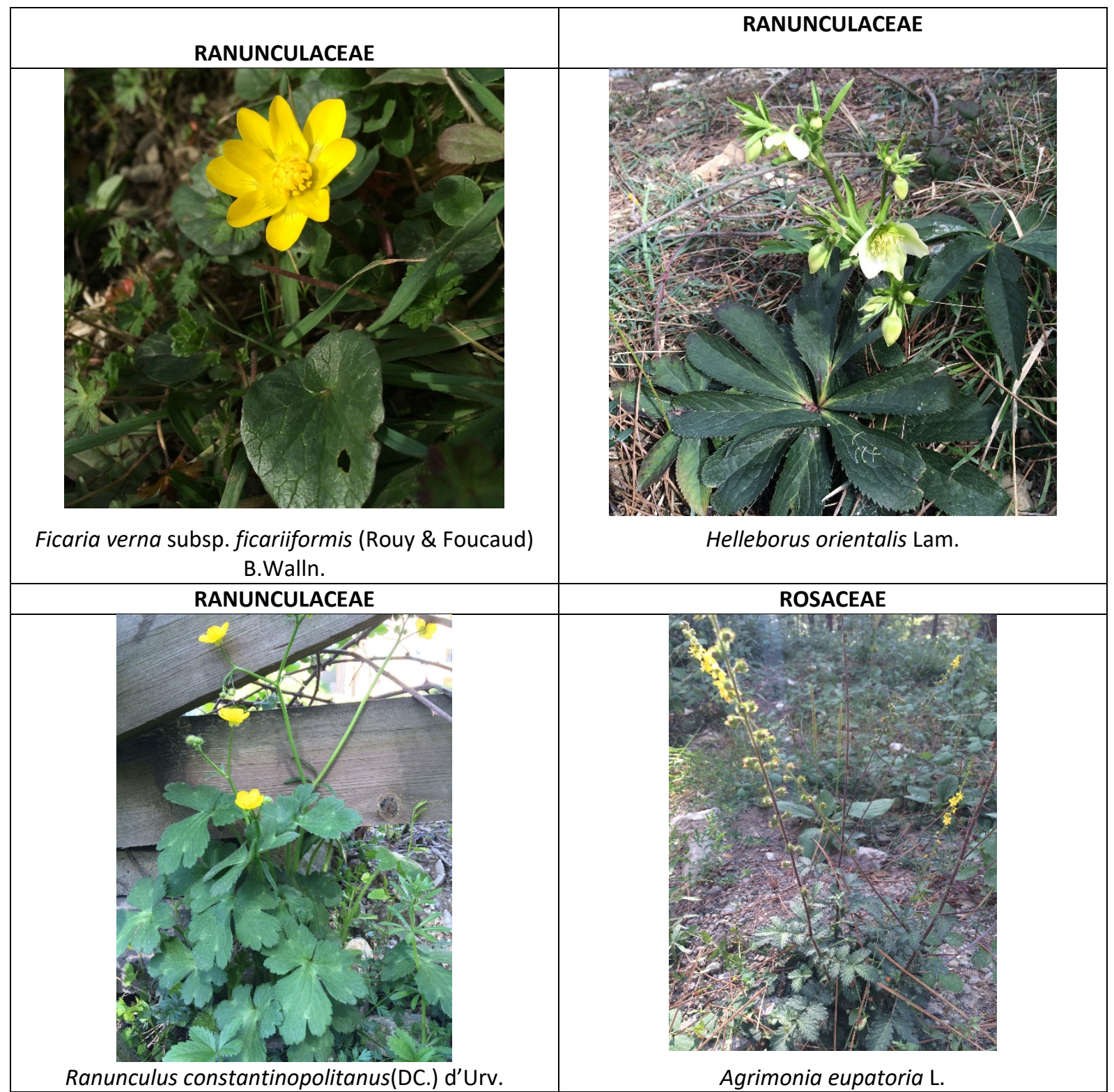




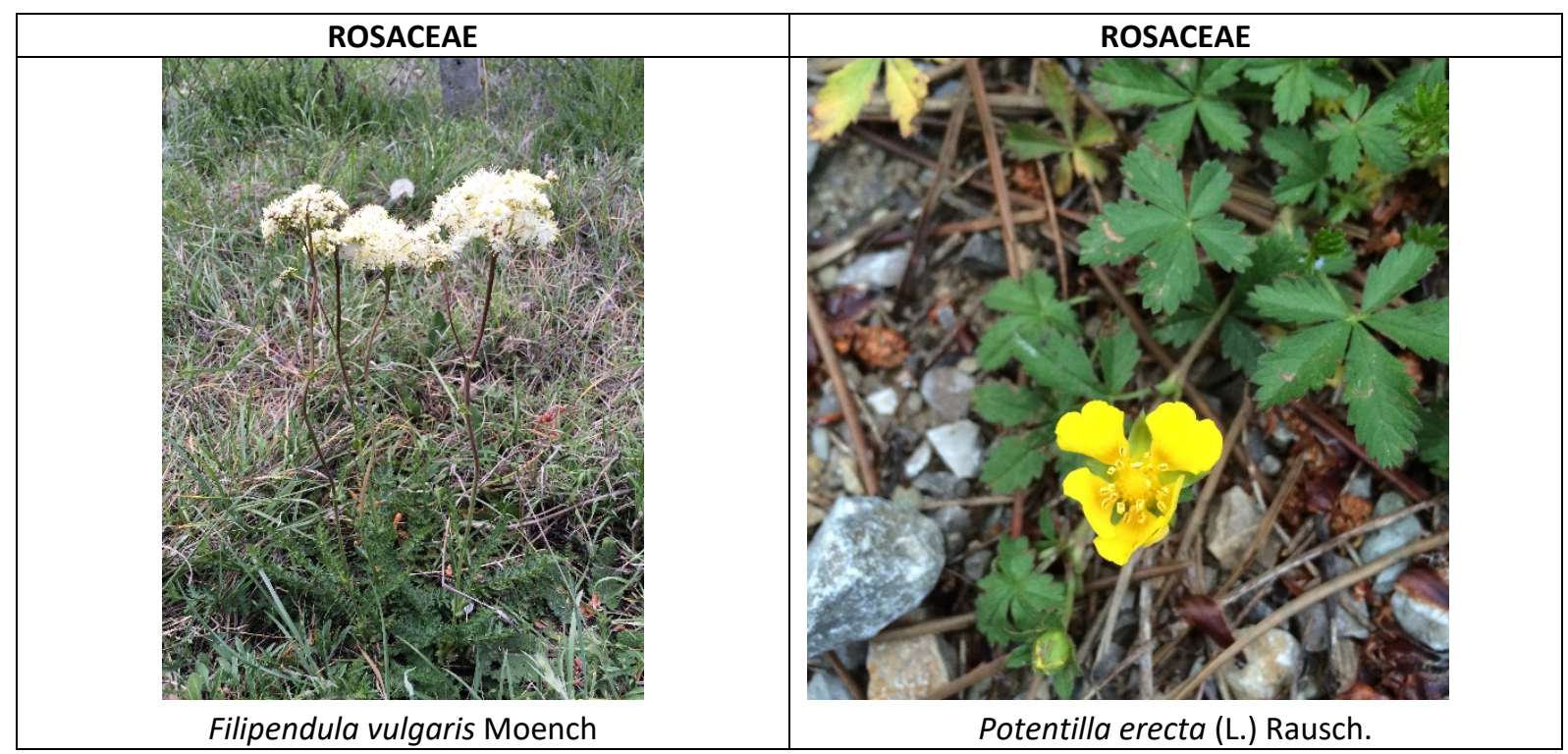

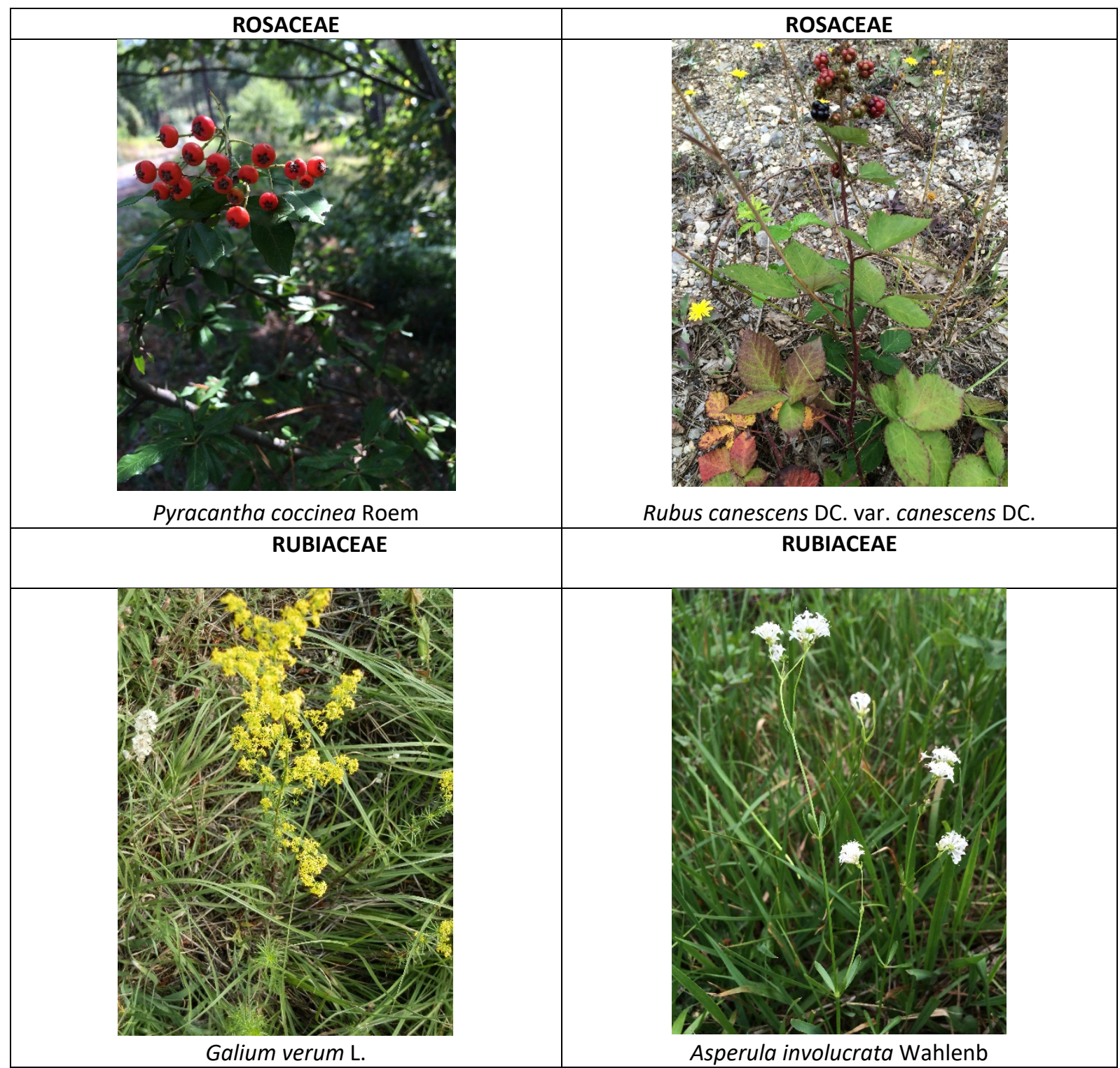




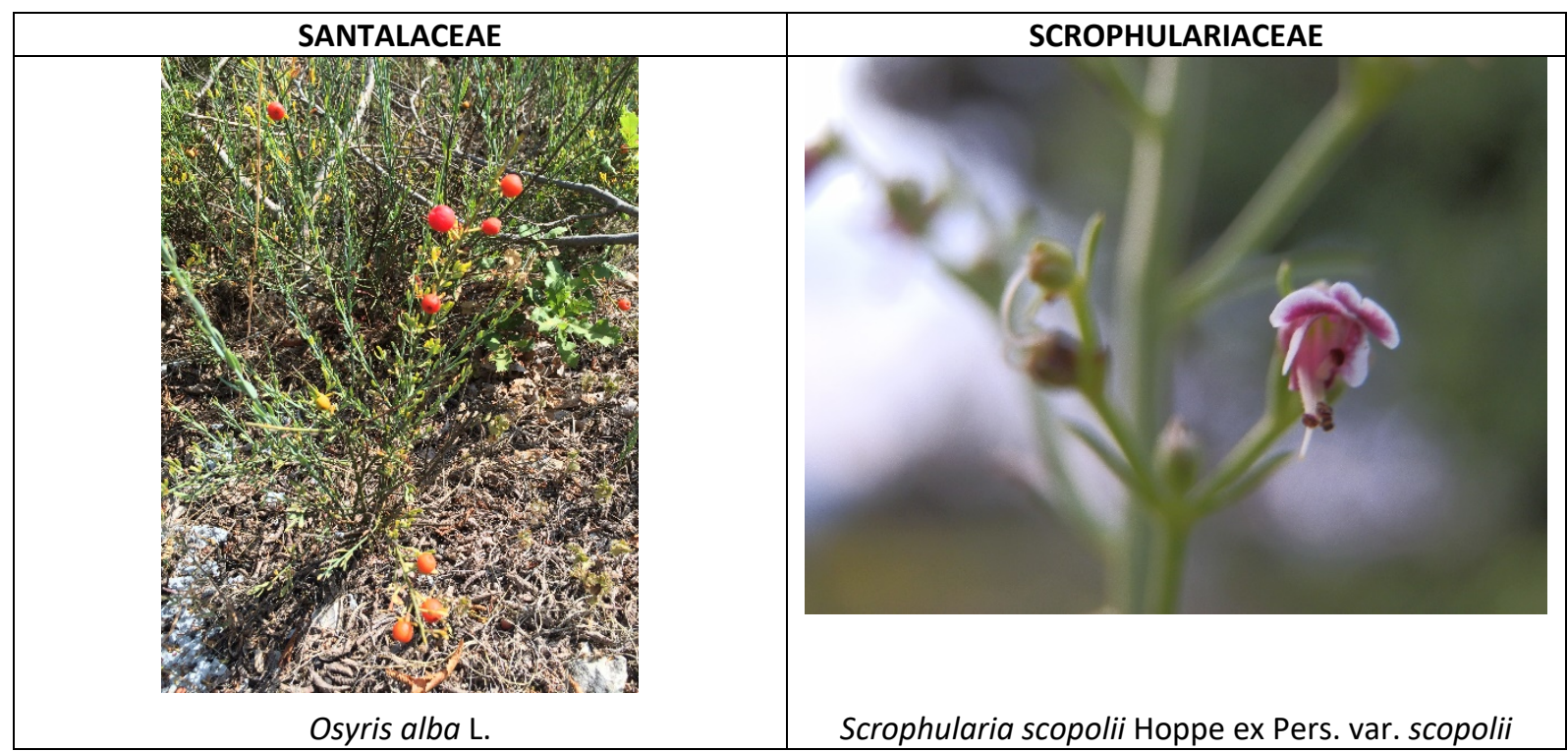

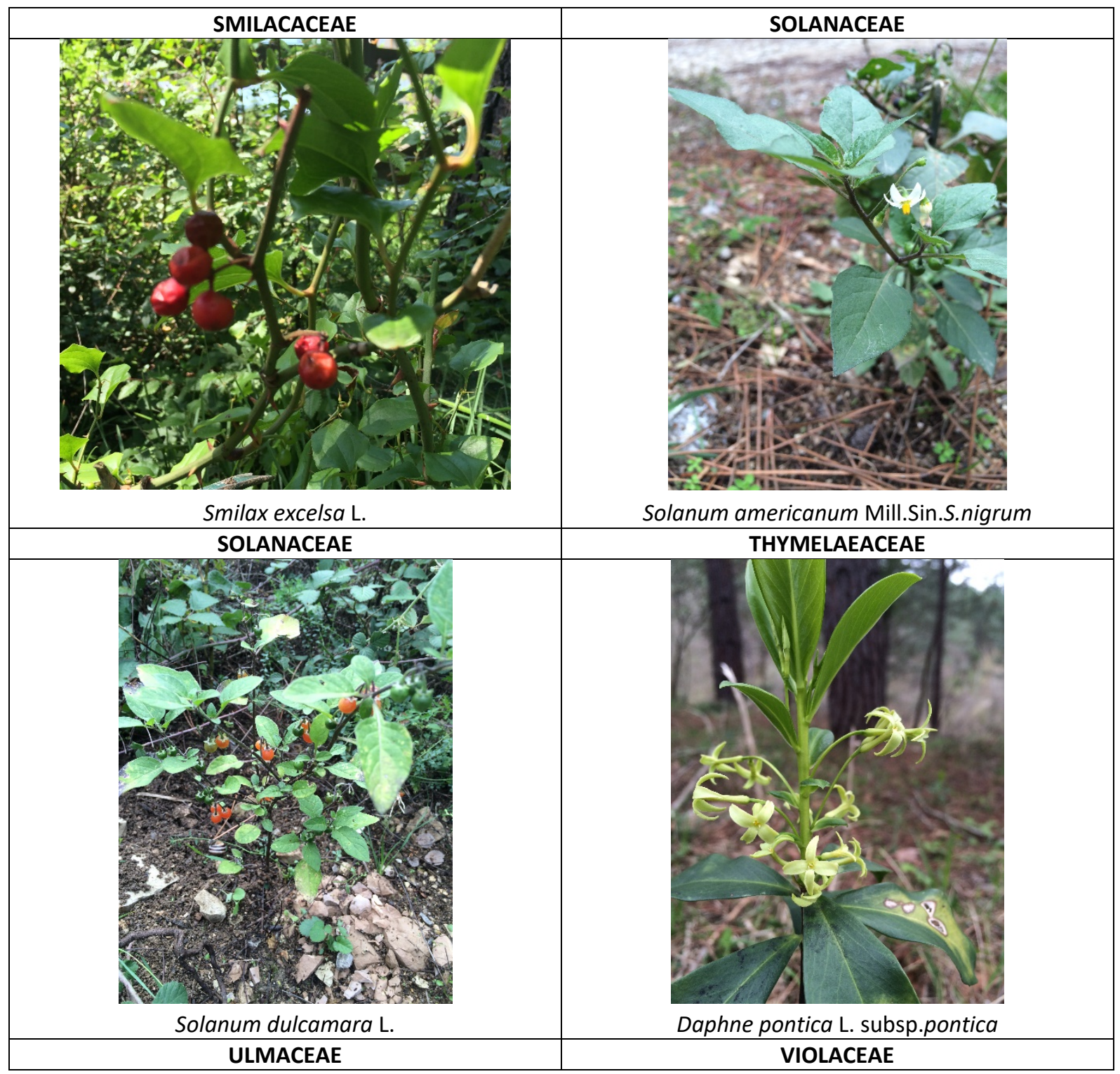




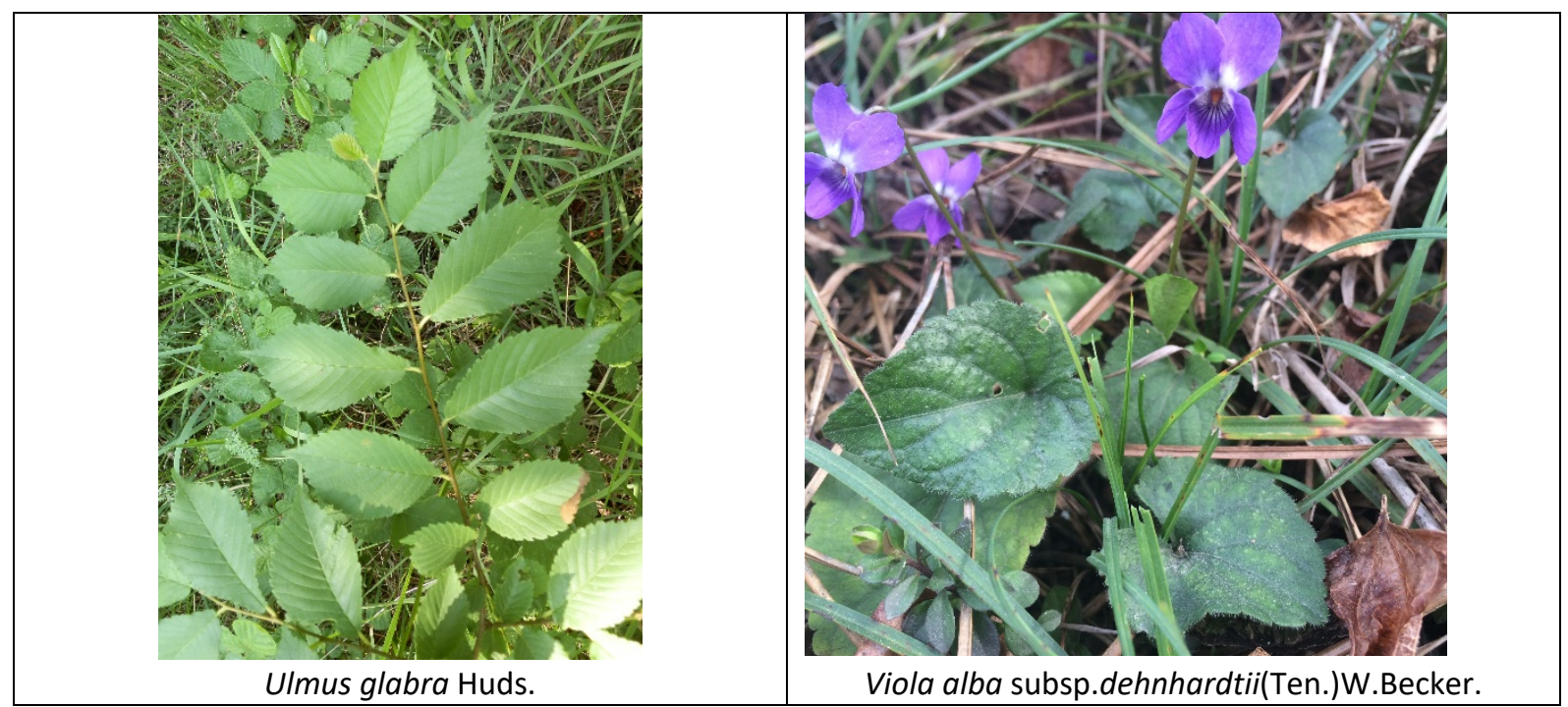

